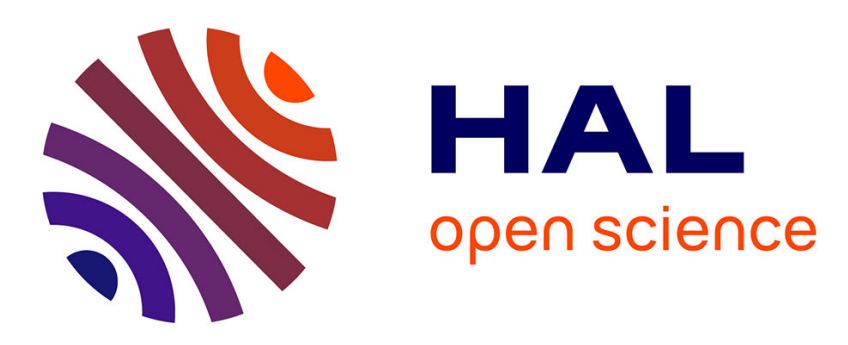

\title{
About the influence of temperature and matrix ductility on the behavior of carbon woven-ply PPS or epoxy laminates: notched and unnotched laminates
}

\author{
Benoît Vieille, Lakhdar Taleb
}

\section{- To cite this version:}

Benoit Vieille, Lakhdar Taleb. About the influence of temperature and matrix ductility on the behavior of carbon woven-ply PPS or epoxy laminates: notched and unnotched laminates. Composites Science and Technology, 2011, 71 (7), pp.998. 10.1016/j.compscitech.2011.03.006 . hal-00743445

\section{HAL Id: hal-00743445 \\ https://hal.science/hal-00743445}

Submitted on 19 Oct 2012

HAL is a multi-disciplinary open access archive for the deposit and dissemination of scientific research documents, whether they are published or not. The documents may come from teaching and research institutions in France or abroad, or from public or private research centers.
L'archive ouverte pluridisciplinaire HAL, est destinée au dépôt et à la diffusion de documents scientifiques de niveau recherche, publiés ou non, émanant des établissements d'enseignement et de recherche français ou étrangers, des laboratoires publics ou privés. 


\section{Accepted Manuscript}

About the influence of temperature and matrix ductility on the behavior of carbon woven-ply PPS or epoxy laminates: notched and unnotched laminates

B. Vieille, L. Taleb

PII:

S0266-3538(11)00096-0

DOI:

10.1016/j.compscitech.2011.03.006

Reference:

CSTE 4945

To appear in:

Composites Science and Technology

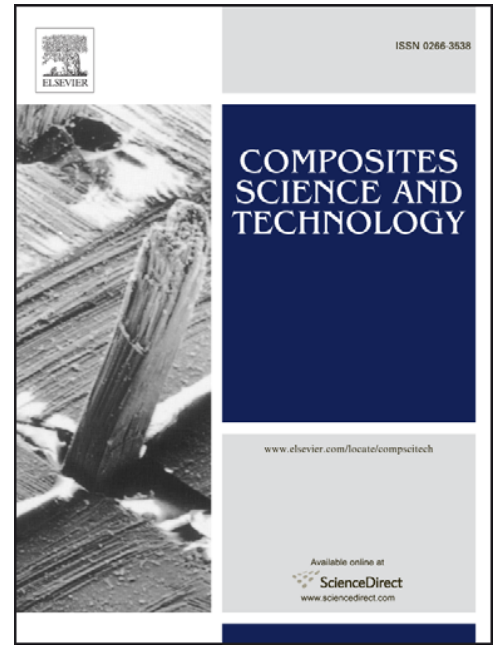

Received Date:

12 October 2010

Revised Date:

11 March 2011

Accepted Date:

12 March 2011

Please cite this article as: Vieille, B., Taleb, L., About the influence of temperature and matrix ductility on the behavior of carbon woven-ply PPS or epoxy laminates: notched and unnotched laminates, Composites Science and Technology (2011), doi: 10.1016/j.compscitech.2011.03.006

This is a PDF file of an unedited manuscript that has been accepted for publication. As a service to our customers we are providing this early version of the manuscript. The manuscript will undergo copyediting, typesetting, and review of the resulting proof before it is published in its final form. Please note that during the production process errors may be discovered which could affect the content, and all legal disclaimers that apply to the journal pertain. 


\title{
ACCEPTED MANUSCRIPT
}

\section{About the influence of temperature and matrix ductility on the behavior of carbon woven-ply PPS or epoxy laminates: notched and unnotched laminates.}

\author{
B. Vieille and L. Taleb \\ Groupe de Physique des Matériaux, UMR 6634 CNRS, INSA de Rouen \\ 76801 Saint Etienne du Rouvray - France \\ * Address correspondence to: Benoit.Vieille@insa-rouen.fr
}

\begin{abstract}
Could thermoplastic-based composites be used to replace thermosetting-based composites in high-temperature secondary aircraft structures ? The purpose of this work is to establish the ability of a material system to be used in aircraft engine nacelles when subjected to static loadings, with a key upper temperature of $120^{\circ} \mathrm{C}$. In order to provide answers to this question, the thermo-mechanical behaviors of carbon fiber fabric reinforced PPS or epoxy laminates have been compared specifically within the temperature change with $120^{\circ} \mathrm{C}$ at the upper bound. The temperature-dependent ductile behavior of laminates is more or less exacerbated, depending on polymers' glass transition temperature, and laminates' stacking sequence. For both materials, the degree of retention of tensile mechanical properties is quite high in notched and unnotched quasi-isotropic laminates. A Digital Image Correlation technique has been used in order to understand the influence of temperature and matrix ductility on the mechanisms of overstresses accommodation near the hole. In fabric reinforced laminates, the hightemperature results suggest a competition between the mechanisms of damage, and the mechanism of plasticization, enhanced in angle-ply lay-ups. Thus, the highly ductile behavior of TP-based laminates, at temperatures higher than their $T_{g}$, is very effective to accommodate the overstresses near the hole.
\end{abstract}

Keywords: A. Fabrics - A. PMCs - B. High-temperature properties - C. Notch 


\section{INTRODUCTION}

Thermosetting (TS) resin-based composite materials have been extensively used over the past 40 years. Even though they display a high degree of mechanical properties retention at high temperature, they also present undeniable drawbacks, such as the need for low-temperature storage, a hard-to-control reticulation process, a very long curing process, and handmade draping, which causes most of the irreversible defects of the manufacturing process. High-performance thermoplastic (TP) resins, such as polyetheretherketone (PEEK) and polyphenylenesulfide (PPS), offer a promising alternative to TS resins such as epoxies: high degree of chemical resistance, excellent damage and impact resistance, and they may be used over a wide range of temperatures. Unlike TS resins, TP resins may be melted down after they are formed, thus providing recycling possibilities and different manufacturing. However, TP composites are more difficult to repair than conventional TS composites, and high-performance TP are more expensive. PPS resin is very thermally stable, it has fire retardant properties, it can attain a high degree of crystallinity (almost 60\%) and it is cheaper than PEEK resin [1]. The basic idea of this work is to find out whether it is possible to replace thermosettingbased composites used in nacelles of plane's engines or not. The service temperature of these nacelles, that usually consist of C/Epoxy laminates, is $120^{\circ} \mathrm{C}$. The question was therefore to evaluate how detrimental such a degree of temperature can be on the behavior of PPS-based laminates compared to epoxy-based laminates. The physical properties (Crystallinity rate and glass transition temperature $\mathrm{T}_{\mathrm{g}}$ ) of TS and TP resins are closely associated with the mechanical behavior of PMCs under high temperatures [2]. An overview of environment effects on performances of PMCs (TS and TP) is proposed in [3]. Around their $\mathrm{T}_{\mathrm{g}}$, the nonlinear behavior of fiber-reinforced polymer composites becomes significant, especially under off-axis loading conditions. This nonlinear response, associated with the shear deformation of the polymer matrix along reinforcing fibers, is enhanced at high temperature depending on the matrix viscoplastic 
nature [4-9]. Very few studies have investigated the high-temperature behavior of PPSbased laminates [10-14] or woven-ply epoxy laminates [15-17].

The fact of joining composites to other structures using mechanical fasteners (bolts or rivets) makes it necessary to drill laminates, which damages both fibers and matrix in the area around the hole. But notches have a significant impact on the growth of damaged zones and on the mechanical properties of laminates. The notch sensitivity, defined by the ratio of laminates' notched and unnotched ultimate strengths, depends on its ability to accommodate overstresses near the hole. This ability, associated with matrix ductility, implies specific damage mechanisms for TP- and TS-based laminates. A good review about the hole sensitivity of TS-based UD laminates is proposed in [18], and a few studies have reported the tensile behavior of notched C/TP (PEEK or PPS) laminates [19-23]. C/PEEK TP composite laminates are more sensitive to the presence of holes than TS laminates. A large amounts of damage have been observed in notched TS composite specimens because of a brittle matrix. Such extensive damages have not been observed in C/PEEK notched laminates because of a much more ductile matrix. In lay-ups with a large percentage of $0^{\circ}$ plies, the presence of larger damage zones at notches in C/epoxy, compared to C/PEEK, permits a reduction of the stress concentration leading to a higher failure load [24]. Most of the attention has been focused on UD ply laminates even though fabric laminates tend to be more resistant to splitting and delamination than similar UD laminates [25]. The occurrence of splitting in UD laminates is facilitated by the low strength in the transverse direction, while delamination can occur due to both Poisson's ratio and shear coupling mismatch. In balanced fabric laminates, $45^{\circ}$ plies are self-balanced and delamination due to shear coupling mismatch is limited. However, both woven-ply and UD-ply C/epoxy exhibit similar notch sensitivity [26]. The effects of matrix ductility (TS and TP) on unnotched/notched carbon woven-ply laminates has been studied in [27]: the failure 
mechanisms of C/epoxy laminates are exclusively governed by the progressive delamination from notch tips, while no appreciable effects are observed on the notch tip fracture of C/TP laminates. To the authors' knowledge, most of the studies on the behavior of notched/unnotched polymer-based composites (TS or TP) have dealt with tests at room temperature. There are no significant results about the high temperature behavior of high-performance TP-based laminates. There is no reference about the plastic accommodation of overstresses, specifically observed in angle-ply notched laminates subjected to tensile loadings.

\section{MATERIAL AND METHODS}

\subsection{Materials}

The composite materials studied in this work are carbon fabric reinforced PPS [11] or epoxy prepreg laminate plates. The toughened PPS resin (Fortron 0214) and the epoxy resin (914) are respectively supplied by the Ticona and by Hexcel. The woven-ply prepreg , supplied by SOFICAR, consists of 5-harness satin weave carbon fiber fabrics (T300 3K 5HS). The volume fraction of fibers is 50\% in C/PPS and C/epoxy laminates. The prepreg plates are hot pressed according to two lay-ups: [0/45/0/45/0/45/0] and $[45]_{7}$. Even though the number of effective plies is higher in $0^{\circ} / 90^{\circ}$ plies than in $45^{\circ}$ plies , the fabric being balanced in warp and weft directions, the first lay-up can almost be considered Quasi-Isotropic (Q-I), and is suitable for applications in aircraft engine nacelles. In Angle-Ply (A-P) laminates $[45]_{7}$, each ply consists of fibers oriented at $+45^{\circ}$ (warp direction), and at $-45^{\circ}$ (weft direction). Even though an A-P lay-up is not suitable for use in aircraft structures, it allows the authors to investigate specifically the plastic accommodation mechanism in order to understand the specific contribution of TP matrix to the high-temperature behavior of high-performance TP-based laminates.

\subsection{Method}




\section{ACCEPTED MANUSCRIPT}

All the quasi-static tests were performed using a $100 \mathrm{kN}$ capacity load cell of an MTS 810 servo-hydraulic testing machine at room moisture. The temperature control system (oven and temperature controller), provided a stable temperature environment during the test. Tensile tests were conducted on notched and unnotched laminates with two stacking sequences. Their mechanical properties were determined according to the EN 6035 (Tensile - Open hole tensile tests) and EN 6031 (In-plane shear test) standards.

Strains are evaluated from an extensometer and V denotes constant crosshead speed (in $\mathrm{mm} / \mathrm{min}$ ) applied to the specimen during displacement-controlled tests. Four specimens were tested in each configuration (See Fig. 1). The mechanical properties were averaged from these values (See Tab. 3 and Tab. 5). The average thickness of specimens is about 2.22mm in C/PPS, and about 2.08mm in C/epoxy.

In accordance with the previous standards, the longitudinal and shearing modulus were calculated from the following definitions :

$$
\begin{aligned}
E_{X} & =\frac{\Delta F^{p}}{S . \Delta \varepsilon_{X}} \\
G_{12} & =\frac{\Delta F}{2 S \cdot \Delta \gamma_{12}}
\end{aligned}
$$

Where $\Delta F$ is the difference in the applied tensile loads at $\left(\varepsilon_{X}\right)_{2}=0.25 \%$ and $\left(\varepsilon_{X}\right)_{1}=0.05 \%$. $\mathrm{S}$ is the specimen cross section.

$\Delta \Upsilon_{12}=\Delta \varepsilon_{X}-\Delta \varepsilon_{y}$ represents the shearing distortion.

$\Delta \varepsilon_{X}=\left(s_{X}\right)_{2}-\left(s_{X}\right)_{1}$ (Difference in the longitudinal strains) and $\Delta \varepsilon_{Y}$ (Difference in the transversal strain) are calculated from the values given by strain gages located along $\mathbf{X}$ and $\mathbf{Y}$ axis (See Fig. 1).

\section{RESULTS}

A Differential Scanning Calorimetry performed by the CRISMAT laboratory on C/PPS gave $\mathrm{T}_{\mathrm{g}}=98^{\circ} \mathrm{C}$ and a cristallinity rate equal to $30 \%$, and $\mathrm{T}_{\mathrm{g}}=190^{\circ} \mathrm{C}$ for $\mathrm{C} / \mathrm{Epoxy}$. Tensile tests have been performed in the direction along the $0^{\circ}$ axis. The modulus and strength in warp and weft directions are assumed to be equal (See Tab. 1). For balanced woven fabrics, it is reasonable to admit such an equality for different composite systems [28]. 
However, such an assumption also depends on the geometry of textile fabric (satin or plain weave). Indeed, it is only verified when the crimp ratio, which represents the undulation of weft fiber bundles over warp fiber bundles, is low e.g. for satin weave fabric[17]. In this latter case, the equality of the elastic properties has been observed experimentally in balanced 5-harness satin weave carbon fiber fabrics reinforced epoxy laminates [15][29]. In a work dealing with the laminate mechanics for balanced woven fabrics [30], Akkerman showed that this assumption is also verified in balanced 5harness satin weave carbon fiber fabrics reinforced PPS laminates.

\subsection{Tensile tests on unnotched laminates}

In Q-I laminates, according to the CLT (Classical Laminate Theory) calculations, the load carried by $0^{\circ}$ plies ( $57 \%$ of the plies) represents $73 \%$ of the total load. Thus, the laminate response is mainly dominated by the behavior of $0^{\circ}$ fibers resulting in a temperature-independent behavior in C/Epoxy and C/PPS laminates (See Fig. 2a and 2b). The dotted line corresponds to the slope at the origin of the curve. It represents a purely elastic response, and emphasizes a behavior characterized by a very low degree of non-linearity. Load/unload tensile tests performed on C/Epoxy laminates (See Fig. 3a) show that, even at 95\% of the load at failure, the longitudinal modulus of the laminate is still very high in comparison with its initial value at both temperatures (See Tab. 2a). It suggests that this slightly non-linear behavior is not associated with the gradual failure of $0^{\circ}$ oriented fibers during loading, but with a localized plastic behavior of $45^{\circ}$ oriented plies. However, such a behavior is limited by the $0^{\circ}$ plies and plasticity cannot develop. At $120^{\circ} \mathrm{C}$, the ductile behavior of the plain PPS resin is enhanced, but the laminate response being mainly fiber-dominated, then the laminate behavior is not significantly influenced by the matrix response at high temperature (See Fig. 4a). For design requirements, it appears that the tensile properties of Q-I C/epoxy laminates are

greater than C/PPS ones (see Tab. 3). This is amplified as temperature increases around 
the $\mathrm{T}_{\mathrm{g}}$ of $\mathrm{C} / \mathrm{PPS}$ composites. In A-P laminates, the matrix-dominated response results in a elastic-ductile behavior (See Fig. 5a and 5b) in both composite systems. From a general standpoint, the in-plane shear properties (modulus and strength) are higher in C/Epoxy than in C/PPS laminates (Tab. 3). Load-unload tensile tests performed on A-P C/Epoxy laminates show a gradual decrease of material's longitudinal modulus (See Fig.4b ) as well as residual strain (See Tab. 2b). These observations highlight two simultaneous mechanisms (damage and plasticization) that will be discussed in the next section. Contrary to the Q-I lay-up, the highly ductile behavior of PPS can be observed in A-P lay-ups (See Fig. 4a), more particularly at $120^{\circ} \mathrm{C}$ because the test temperature is higher than its $\mathrm{T}_{\mathrm{g}}$. Thus, the shear modulus decreases more in C/PPS (-67\% ) than in C/Epoxy laminates (-21\%). Both materials have virtually the same strength at both temperatures, but the elongation at failure is a lot more significant in C/PPS laminates ( $+420 \%$ at RT and $+367 \%$ at $\left.120^{\circ} \mathrm{C}\right)$. The CLT and the Tsai-Hill failure criterion gives the failure strengths with an acceptable relative change (See Tab. 4).

The in-plane shear stress-strain response of both materials consists of different regimes. The initial one is elastic. It is followed by a non-linear region which began with the onset of matrix plastic deformation, and which was fully developed at shear strains of 3$6 \%$ in C/epoxy and 17-27\% in C/PPS. The stress borne by the composite increased linearly until failure afterwards, as the displacement compatibility between matrix and fibers led to the progressive rotation of the latter with the applied shear strain and increased the axial stresses borne by the fibers [31]. In epoxy-based laminates, the low ductile behavior of epoxy matrix does not allow the fibers to rotate a lot (About $5^{\circ}$ at $\mathrm{RT}$ and $7^{\circ}$ at $120^{\circ} \mathrm{C}$ - See Fig. 6). The development of interface fracture significantly modified the in-plane shear behavior as it hindered the load transfer between matrix and fibers and precipitated fracture by the coalescence of interface cracks. The observation of the fracture surface indicates that the specimen failure is associated with the onset of 
a shearing band oriented at $45^{\circ}$ (See Fig. 6) in reference to the loading direction [32]. In the case of PPS-based laminates, the highly ductile behavior of PPS matrix limits the development of interface fracture, and promotes the rotation (About $17^{\circ}$ at $\mathrm{RT}$ and $26^{\circ}$ at $120^{\circ} \mathrm{C}$ - See Fig. 6). Such mechanisms cause necking that is clearly observable on the C/PPS stress-strain curves, as well as on the failed specimens. Necking comes along with an important delamination. The magnitude of the maximum rotation of fibers bundles can be evaluated in unnotched laminates at both temperatures (See Fig. 6). Such an assessment of fibers rotation rests on the observation of the fibers at the specimen surface. It is therefore not very accurate in comparison to the evaluation of the rotation and the progressive development of damage done by optical microscopy [31]. According to the conclusions done in [16][17] for woven-ply composites, and depending on matrix nature, cracks appear within fiber bundles and in the area where the weft fibers undulate over warp fibers. It results in the splitting of the initially perpendicular weft and warp fibers bundles.

\subsection{Tensile tests on notched laminates}

The hole factor $\mathcal{C}_{\mathrm{h}}$ represents the hole sensitivity of the laminate ultimate strength. It is defined by $C_{h}=\frac{\sigma_{\text {notehed }}^{u}}{\sigma_{\text {unnotehed }}^{\mathrm{u}}}$ where $\sigma_{\text {notched }}^{\mathrm{u}}=\Gamma_{\text {notched }}^{\mathrm{u}} / \mathrm{t} . \mathrm{w}$ and $\sigma_{\text {unnotched }}^{\mathrm{u}}=\mathrm{F}_{\text {unnotched }}^{\mathrm{u}} / \mathrm{t}$ w are respectively the notched and unnotched ultimate stresses, $\mathrm{t}$ and $\mathrm{w}$ being the thickness and width of the specimens. From these definitions, the tensile responses can be compared for both materials at both temperatures (Fig. 2 and Fig. 5). In Q-I laminates, temperature influences very little both strength and stiffness of both materials (See Tab. 5). The hole factor increases very little bit showing that hole sensitivity is almost temperature-independent in fiberdominated laminates. Thus, a service temperature equal to $120^{\circ} \mathrm{C}$ is not significantly detrimental for the tensile behavior of notched laminates with a Q-I lay-up. In A-P 
laminates, the ductile behavior of the polymer matrix is more or less enhanced at high temperature depending on the matrix. It contributes to adversely affect the mechanical properties of both materials. However, they become less hole-sensitive as temperature increases (See Tab. 5). C/PPS is less resistant (about -20\%) than C/Epoxy, and elongation at failure in C/PPS is much more pronounced than in C/Epoxy.

\section{DISCUSSION}

Knowledge of the extent of strains at stress concentrators like holes is important in engineering design because it is associated with the magnitude of the localized stresses at the discontinuity, and hence the notched strength of the structure. In order to study the influence of temperature and matrix ductility on the mechanisms of overstresses accommodation near the hole, a Digital Image Correlation technique has been used. It gives qualitative and quantitative information about strains fields. The following discussion is based on the damage mechanisms in woven-ply notched laminates reported in [21][25][27] at RT, as well as under high-temperature [8][16][30].

\subsection{Digital Image Correlation technique for strain field measurements}

Full-field measurement techniques using Digital Image Correlation are an effective method in investigating the behavior of heterogeneous materials such as composite structures. This technique is of great interest for the detection of damage zones, and for quantifying their increase, particularly, in high gradients zones. Strains fields around holes can be measured by DIC or optical systems using laser speckle pattern method [24][34-35]. The ability of DIC to measure full-field in-plane surface deformations at high temperatures was evaluated in [36]. The DIC technique consists in painting the sample white, and then in sputtering black paint on the surface of the sample in order to get a painting with different grey value patterns. When a displacement is applied to the sample, a Region Of Interest around the hole is filmed with a CCD video camera, whose 
resolution is 659*493 pixels, and which is equipped with a zoom lens. DIC is based on the comparison of specimen's images acquired at $10 \mathrm{~Hz}$ by the software Visionstage.

Two images are chosen at two specific strain states : before the test starts and just before failure. The correlation software VIC2D tracks blocks of pixels in order to measure surface displacement and build up full field 2D strain maps. The hole being a singularity at the surface of the specimen, the blocks of pixels located on the notch boundary cannot be used for calculating the strain field. Thus, the offset in the hole's radius represents the area where the calculation is not possible. The strain maps built gives the in-plane Green-Lagrange strain field. The local accuracy of these values depends on many parameters : fineness and density of the sputtered black painting on the white surface, the grid step, the pattern size and the heterogeneity of laminates. The use of a DIC technique at high temperature requires to film the specimen through a porthole’ glass, making necessary to avoid catch lights on the porthole's glass that might be detrimental for the accuracy of calculated strain fields. For each lay-up, the comparison of strain components $E_{Y Y}(Y$ being the loading axis) at both temperatures reflects the influence of matrix ductility on the mechanisms of overstresses accommodation near the hole via changes in overstrains fields. The overstrain coefficient can be defined as the ratio of the maximum strain near the hole over the strain applied to the specimen.

\subsection{Quasi-isotropic laminates}

In woven-ply C/Epoxy laminates, notch-tip blunting (splitting) is known to reduce the stress concentration effect of the notch, and then to limit the laminate's hole sensitivity in Q-I laminates [19][20]. Contrary to UD-ply laminates [33][34], there is no clear sign of delamination in woven-ply C/Epoxy laminates [27], where $45^{\circ}$ plies are selfbalanced, and delamination due to shear coupling mismatch is limited. In such materials, transverse and longitudinal cracks appear early during tensile tests. They extend fast and widely around the hole, whereas in C/TP laminates, damage and plastic 
strains remain localized in the hole vicinity [8][10]. According to X-ray observations [34], splitting appears later and is less extended than in C/Epoxy, resulting in a higher notch sensitivity of C/TP [27][33-35]. In the present work, Figure 3b shows that the residual strains after unloading are very small (less than $0.07 \%$ ) in notched laminates for both materials. It suggests that plasticity cannot develop in the $45^{\circ}$ plies of in Q-I laminates, even at $120^{\circ} \mathrm{C}$ when the polymer matrix ductile behavior becomes more significant. When the $0^{\circ}$ fibers break, the load is transferred transversely to the adjacent fibers that progressively fail until final failure of laminates. Thus, the fracture surfaces is characterized by a transverse failure mode (See Fig. 11). In C/Epoxy laminates, fracture surfaces are similar across the range of test temperatures. At RT, the profile of the fracture surface is typical of brittle fracture with almost no bare fibers and no hackles (See Fig. 11a), and almost no delamination as the edge views of failed notched specimens can suggest it (See Fig. 12a). At $120^{\circ} \mathrm{C}$, grooves can be clearly observed in the fracture area between plies what means fracture is dominated by matrix cleavage (See Fig. 11b). The tensile responses and fracture surfaces of Q-I C/Epoxy laminates suggest that damage mechanisms do not seem to change significantly as temperature increases. It results in very similar longitudinal strain fields at both temperatures (See Fig. 7). Observation of stress-strain curves suggests a catastrophic failure of notched specimens as in the unnotched case (See Fig. 2). Observations of fracture surface in C/PPS laminates show bare fibers in hackles configuration (See Fig. 11a), confirming the relatively weak fiber/matrix bond that was observed in unnotched laminates [13]. At $120^{\circ} \mathrm{C}$, as the number of bare fibers has increased, it is reasonable to conclude that interfacial bond has degraded and interfacial failure has become extensive (See Fig. 11b), resulting in some delamination visible on the edge views of failed notched specimens (See Fig. 12a). Thus, the longitudinal strain fields are different at RT and $120^{\circ} \mathrm{C}$ (See Fig. 8). 
In Q-I laminates, the strain concentration increases significantly with increasing temperature for both materials (See Tab. 6), but in the meantime, the hole factor slightly increases (See Tab. 5). It suggests that the effect of notch is locally enhanced by the increase in temperature whereas the notch sensitivity (being the reverse of the hole factor) slightly decreases for both materials. On the one hand, the ductile behavior of both matrix systems is enhanced at $120^{\circ} \mathrm{C}$, but the matrix behavior is limited by the Q-I lay-up. On the other hand, the strength of the fiber/matrix bond and the interlaminar shear strength decrease as temperature increases. It results in a little more extended damage near the hole (splitting) which is combined with a more extended plastic behavior at high temperature. It explains why the strain concentration increases with temperature. From the overstresses accommodation standpoint, these mechanisms contribute to a little release of stresses in the bundles of fibers near the damaged /plasticized area. Thus, the hole sensitivity slightly decreases, but the C/PPS mechanism associated to the ductile nature of PPS is slightly less effective than C/Epoxy one.

\subsection{Angle-ply laminates}

The tendency is different from the one observed in the Q-I laminates because the mechanical behavior of A-P laminates is mainly matrix-dominated. Consequently, they are less hole-sensitive, more particularly at $120^{\circ} \mathrm{C}$ (See Tab. 3 and 5). The ability of the matrix to transmit load to fibers becomes impaired at high temperature, but plasticity is more or less exacerbated depending on the matrix nature. While matrix undergoes a plastic deformation along the $45^{\circ}$ oriented fibers, these fibers tend to rotate (See

Section 3.1) . Because of the undulation of weft fibers over warp fiber bundles, weft fibers are overstressed and fail first, resulting in failure surfaces oriented along the warp direction. Even though matrix ductility has an impact on stresses distribution around the hole through a plasticity mechanism, it is not the only mechanism for 
accommodating overstresses. In C/PPS laminates, cracks along $45^{\circ}$ fibers and some fiber/matrix debonding can be observed in the $45^{\circ}$ direction to the hole as well as delamination (See Fig. 12b). The longitudinal strain fields are very different at both temperatures (See Fig. 10), because plasticity is prominent in PPS-based laminates along the $45^{\circ}$ oriented fibers. It finally results in a lower strain concentration near the hole as temperature increases (See Tab. 6). It also suggests that there is competition between the mechanism of damage and the mechanism of plasticization enhanced by a temperature increase. Such mechanisms contribute to release the stresses near the hole, hence a better notch sensitivity at high temperature. In C/Epoxy laminates, the tensile responses (See Fig. 2b) show that the ductile behavior is slightly enhanced at $120^{\circ} \mathrm{C}$ what contributes to moderate changes in damage mechanisms as temperature increases. The longitudinal strain fields are very similar at both temperatures (See Fig. 9), and the overstrain coefficients are virtually the same (See Tab. 6). The observations of failure surfaces show interfacial debonding in warp and weft directions (stairs profile) along the $45^{\circ}$ direction, and some delamination (See Fig. 12b). These mechanisms combined with a larger plastic deformation along the $45^{\circ}$ oriented fibers cause the increase of C/Epoxy laminates' hole factor with increasing temperature. Still considering the detrimental effect of a temperature increase on the strength of the matrix, of the fiber/matrix bond and interlaminar shear strength, damage appears earlier than at RT. Both mechanisms (plasticization and damage) counter act, resulting in virtually the same strain concentration. Thus, the hole sensitivity is almost temperature-independent in A-P epoxy-based laminates. Lastly, these mechanisms are very effective because the ultimate notched strength is equal to $82 \%$ of the unnotched laminate's strength. The prominent plastic accommodation observed at high temperature in notched C/PPS laminates remains less effective than C/Epoxy one, due to less degree of stress relieving damage formation around the notch. 


\section{CONCLUSION}

Changes in the mechanical behavior of notched/unnotched laminates were investigated in carbon fabric reinforced PPS and epoxy laminates between RT and $120^{\circ} \mathrm{C}$.

Considering the results of the present study, PPS-based composites can be used to replace epoxy-based composites in high-temperature secondary aircraft structures subjected to static loadings. Despite the maximum test temperature $\left(120^{\circ} \mathrm{C}\right)$ is higher than its $\mathrm{T}_{\mathrm{g}}\left(98^{\circ} \mathrm{C}\right)$, the degree of retention of mechanical properties at elevated temperature is very high in both notched and unnotched C/PPS laminates with a Q-I layup. Far from epoxy’s $T_{g}$, a high temperature has also very little influence on both notched and unnotched tensile properties of C/Epoxy laminates. In A-P laminates, changes in mechanical properties and failure mechanisms are significant in both materials even though the epoxy matrix ductility at $120^{\circ} \mathrm{C}$ is less significant than the PPS matrix one. From the overstrain coefficient, it is possible to evaluate the efficiency of the plastic accommodation mechanism to limit overstresses near the hole. It is salient that a temperature increase has a positive impact on the hole sensitivity of both materials (+34\% in C/PPS and +9\% in C/Epoxy laminates). The issue of TS vs TP composites was first addressed 20 years ago, and since then, it is known that the ability of a material to accommodate overstresses near the hole at RT is less effective in C/TP than in C/Epoxy laminates, due to less degree of stress relieving damage formation around the notch. At high temperature, the contribution to knowledge base from this work rests on the emphasis of plastic accommodation mechanisms near the hole in both warp and weft directions. Such mechanisms are specific to woven-ply TP-based laminates at temperatures higher than their Tg, when the TP matrix behavior becomes highly ductile. These mechanisms are effective to release overstresses resulting in lower hole-sensitivity. At last, it is still necessary to investigate the long-term behavior of both notched/unnotched woven-ply laminates over the same range of temperature, before 
such materials can actually be considered for applications in aircraft engine nacelles. A

further work will deal with these issues in order to understand how the specific

accommodation mechanisms near the hole and the corresponding damage accumulation change over time due to environmental factors and cyclic (or creep) loading.

\section{ACKNOWLEDGEMENTS}

This work is a part of the TOUPIE project, and is supported by the DGE through the

MOV'EO competitiveness cluster, in which several partners are collaborating (Région

Haute-Normandie, Aircelle, AMPA, AXS Ing., Université du Havre, ENSI Caen, ENSM Paris, INSA Rouen).

\section{REFERENCES}

1. F.A. Myers. Stress-state effects on the viscoelastic response of PPS-based thermoplastic composites. Advances in TP Matrix Comp. Mat., ASTM STP 1044, 154-162, 1989.

2. J.E. Spruiell, C.J. Janke. A review of the measurement and development of crystallinity and its relation to properties in neat PPS and its fiber reinforced composites. Tech. report, Metals and Ceramics Division, US Dept of Energy, 2004.

3. N.L. Hancox. Overview of effects of temperature and environment on performance of polymer matrix composite properties. Plastics Rubber and Comp. Process. and Applic., 27 (3), 97-106, 1998.

4. M. Kawai, S. Yajima, A. Hachinohe, Y. Kawase. High-temperature off axis fatigue behaviour of unidirectional CFR composites with different resin matrices. Comp. Sc. and Tech., 61, 1285-1302, 2001.

5. M.C. Lafarie-Frenot, F. Touchard. Comparative in-plane shear behaviour of longcarbon-fibre composites with TS or TP matrix. Comp. Sc. and Tech., 52(3), 417-425, 1994.

6. S. Deng, X. Li, H. Lin, J. Weitsman. The non-linear response of quasi-isotropic composite laminates. Comp. Sc. and Tech., 64(10-11), 1577-1585, 2004.

7. S.K. Ha, Q. Wang, F-K. Chang. Modeling the viscoplastic behavior of fiberreinforced TP matrix composites at elevated temperatures. J. Comp. Mat., 25 (4), 334-374, 1991. 
8. M.H.R Jen, Y.C. Tseng, S.C. Chang, M. Chen. Mechanical properties in notched AS4/PEEK APC2 composite laminates at elevated temperature. J. Comp. Mat., 40(11), 955-969, 2006.

9. I. De Baere, W. Van Paepegem, J. Degrieck. Modeling the nonlinear shear stressstrain behavior of a CFR PPS from rail shear and $[45,-45]_{4 s}$ tensile test. Polymer Comp, 1016-1026, 2009.

10. D. Meyer, H. Bersee, A. Beukers. Temperature effect on reinforced TP composite properties for primary aircraft structure applications. In: Proceedings of $49^{\text {th }}$ Struct., Structural Dyn. and Mat. Conference. Seattle, WA, April, 2008.

11. B. Vieille, J. Aucher, L. Taleb. Influence of temperature on the behavior of carbon fiber fabrics reinforced PPS laminates. Mat. Sc. Eng. A, 517, 51-60, 2009.

12. J.S. Loverich, B.E. Russel, S.W. Case, K.L. Reifnider. Life of PPS composites subjected to cyclic loading at elevated temperatures. Time dependent and nonlinear effects. Polymer Comp., 310-317, 2000.

13. C.A. Mahieux, C. Scheurer. Elevated temperature bending stress rupture behavior AS4/APC2 and comparison with AS4/PPS. Comp. Part A, 33, 935-938, 2002.

14. Y. Miyano, M.K. McMurray, J. Enyama, M. Nakada. Loading rate and temperature dependence of flexural fatigue behavior of a satin woven CFRP laminate. J. Comp. Mat., 28(4), 1250-1260, 1994.

15. J.L. Abot, A. Yasmin, A.J. Jacobsen, I.M. Daniel. In-plane mechanical, thermal and viscoelastic properties of satin fabric carbon/epoxy composite. Comp. Sc. and Tech., 64(2), 263-268, 2004.

16. M. Kawai, T. Taniguchi. Off-axis fatigue behavior of plain weave carbon/epoxy fabric laminates at room and high temperatures and its mechanical modeling. Comp. Part A, 37, 243-256, 2006.

17. T. Osada, A. Nakai, H. Hamada. Initial fracture behavior of satin woven fabric composites. Comp. Struct., 61, 333-339, 2003.

18. J. Awerbuch, M.S. Madhukar. Notched strength of composite laminates: Predictions and experiments - A review. J. Reinf. Plast. Comp., 4, 3-159, 1985.

19. L.A. Carlson, C.G. Aronsson, J. Backlund, Notch sensitivity of thermoset and thermoplastic laminates loaded in tension. J. Mat. Sc., 24, 1670-1682, 1989.

20. P.A. Lagace, N.V. Bhat, A. Gundogdu. Response of notched C/epoxy and C/PEEK systems. Comp. Mat. : Fatigue and Fracture, ASTM STP 1156, 1993.

21. F. Touchard-Lagattu, M. C. Lafarie-Frenot. Damage and inelastic deformation mechanisms in notched TS and TP laminates. Comp. Sc. and Tech., 56(5), 557-568, 1996.

22. F. Touchard, M. C. Lafarie-Frenot, D. Guédra-Degeorges. Mechanical behaviour characteristics of a TP composite used in structural components. Comp. Sc. and Tech., 56(7), 785-791, 1996. 
23. F. Aymerich, M.S. Found. Response of notched AS4/PEEK and C/epoxy laminates subjected to tension fatigue loading. Fatigue and Fracture of Eng. Mat. and Struct., 23(8), 675-682, 2000.

24. J. Brillaud, M.C. Lafarie-Frenot, F. Touchard, Experimental determination by laser speckle patterns of plastic strains near a hole in a TP composite laminate. In: Proc. $10^{\text {th }}$ Int. Conf. on Experim. Mech. , Balkema, Lisbon, 343-348, 1994.

25. E. de Azevedo Soriano, S.F.M. de Almeida. Notch sensitivity of C/epoxy fabric laminates. Comp. Sc. and Tech., 59, 1143-1151, 1999.

26. P.A. Lagace. Notch sensitivity of graphite/epoxy fabric laminates. Comp. Sc. and Tech., 26, 95-117, 1986.

27. M. Kawai, M. Morishita, K. Fuzi, T. Sakurai, K. Kemmochi. Effects of matrix ductility and progressive damage on fatigue strengths of unnotched / notched CF plain woven roving fabric laminates. Comp. Part A, 27(6), 493-502, 1996.

28. N.K. Naik, V.K. Ganesh. Prediction of on-axes elastic properties of plain weave fabric composites. Comp. Sc. and Tech., 45(2), 135-152, 1992.

29. I.M. Daniel, J-J. Luo, P.M. Schubel. Three-dimensional characterization of textile composites. Comp. Part B, 39, 13-19, 2008.

30. R. Akkerman. Laminate mechanics for balanced woven fabrics. Comp. Part B, 37(23), 108-116, 2006.

31. E. Totry, J. M. Molina-Aldareguia, C. Gonzalez, J. LLorca. Effect of fiber, matrix and interface properties on the in-plane shear deformation of CFR composites. Comp. Sc. and Tech., 70(6), 970-980, 2010.

32. M. Karayaka, P. Kurath. Deformation and failure behavior of woven composite laminates. J. Eng. Mat. Tech., ASME, 116(2), 222-232, 1994.

33. K.D. Cowley, P.W.R. Beaumont. Damage accumulation at notches and the fracture stress of carbon-fibre/polymer composites: Combined effects of stress and temperature. Comp. Sc. and Tech., 57(9-10), 1211-1219, 1997.

34. F. Lagattu, J. Brillaud, M. C. Lafarie-Frenot. High strain gradient measurements by using digital image correlation technique. Mat. Charact., 53(1), 17-28, 2004.

35. F. Lagattu, M.C. Lafarie-Frenot, T.Q. Lam, J. Brillaud. Experimental characterisation of overstress accommodation in notched CFRP composite laminates. Comp. Struct., 67, 347-357, 2005.

36. J.S. Lyons, J. Liu, M.A. Sutton. High-temperature deformation measurements using digital-image correlation. Experim. Mech., 36(1), 64-70, 1996. 


\section{Figure captions}

Fig. 1 - Geometry of tensile specimens: (a) notched - (b) unnotched

Fig. 2 - Tensile vs open hole tensile tests at both temperatures on Q-I laminates: (a) C/PPS - (b) C/Epoxy

Fig. 3 - Load/unload tensile tests on Q-I laminates: (a) unnotched C/Epoxy - (b) notched C/Epoxy and C/PPS at $120^{\circ} \mathrm{C}$

Fig. 4 - Comparison of mechanical responses: (a) Q-I and A-P C/PPS laminates vs plain PPS resin - (b) Load/unload tensile tests on A-P C/Epoxy laminates

Fig. 5 - Tensile vs open hole tensile tests at both temperatures on A-P laminates:

(a) C/PPS - (b) C/epoxy

Fig. 6 - Rotation of fibers bundles for both materials: (a) RT - (b) $120^{\circ} \mathrm{C}$

Fig. 7 - Quasi-isotropic C/Epoxy laminates at RT and $120^{\circ} \mathrm{C}$. Comparison of failed specimens (transverse failure in weft direction) and corresponding Green-Lagrange longitudinal (warp direction =y) strain fields obtained by Digital Image Correlation: the longitudinal overstrain near the hole increases with temperature (+40\%)

Fig. 8 - Quasi-isotropic C/PPS laminates at RT and $120^{\circ} \mathrm{C}$. Comparison of failed specimens (transverse failure in weft direction) and corresponding longitudinal (warp direction $=$ y) strain fields obtained by Digital Image Correlation: the longitudinal overstrain near the hole increases a lot with temperature (+158\%)

Fig. 9 - Angle-ply C/Epoxy laminates at RT and $120^{\circ} \mathrm{C}$. Comparison of failed specimens (shearing band along the warp direction) and corresponding longitudinal strains fields obtained by Digital Image Correlation: the longitudinal overstrain near the hole is virtually the same at both temperatures $(+6 \%)$

Fig. 10 - Angle-ply C/PPS laminates at RT and $120^{\circ} \mathrm{C}$. Comparison of failed specimens (failure along warp and weft directions at RT - failure along warp direction at $120^{\circ} \mathrm{C}$ ) and corresponding longitudinal strains fields obtained by Digital Image Correlation: the longitudinal overstrain near the hole decreases a lot with temperature (-52\%) due to extended plastic deformation along the $45^{\circ}$ oriented fibers

Fig. 11 - Quasi-isotropic notched failed specimens:

(a) Side macro views of fracture surfaces highlight the transverse failure mode - (b) Alternative views showing the specific fracture mechanisms in each material Fig. 12 - Edge views of notched failed specimens: (a) quasi-isotropic - (b) angle-ply 
(a)

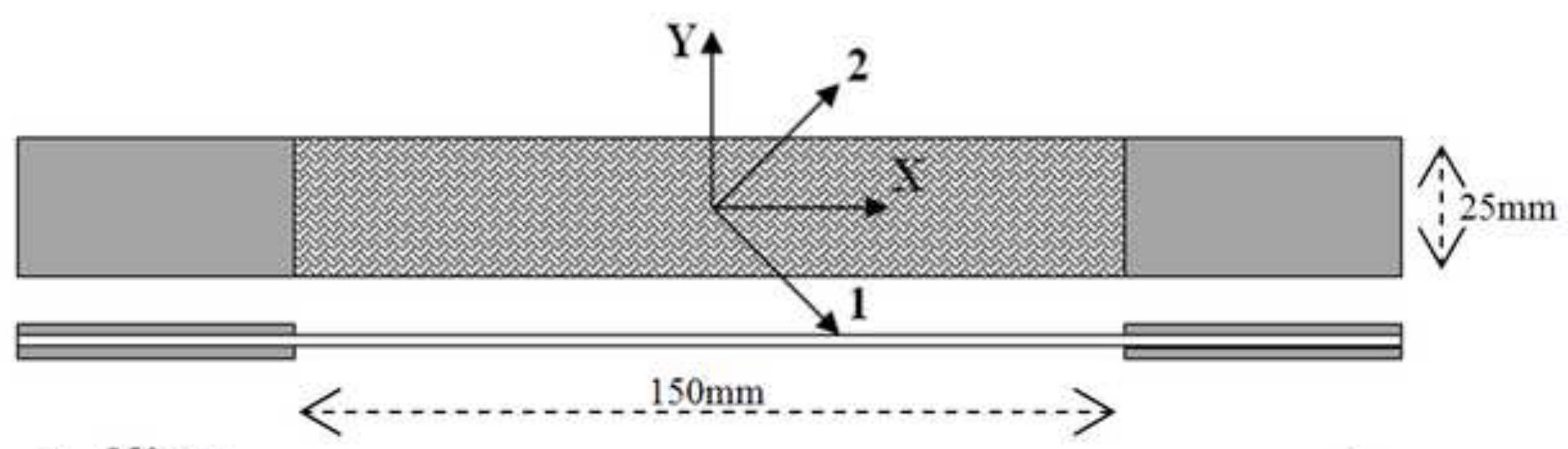

$<250 \mathrm{~mm}$

(b)

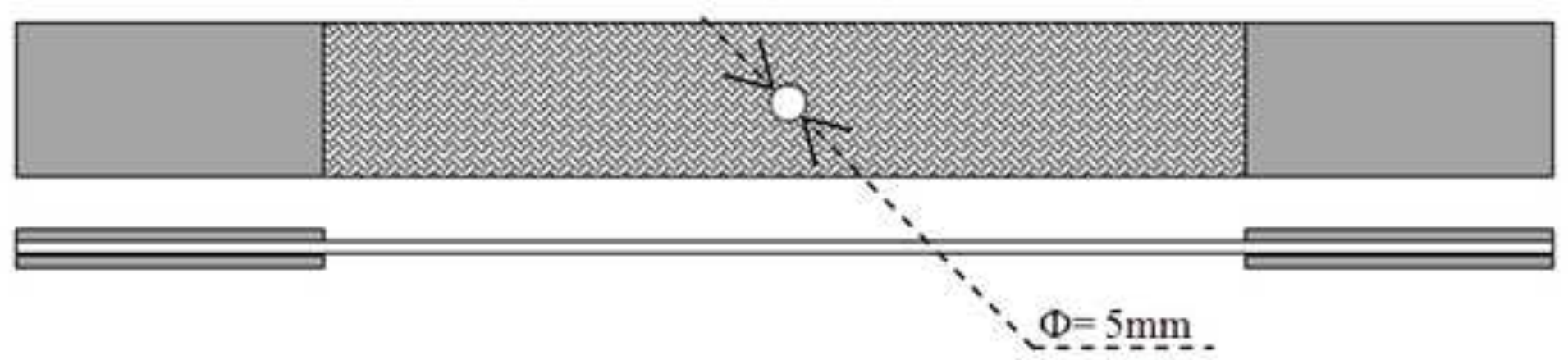


(a)

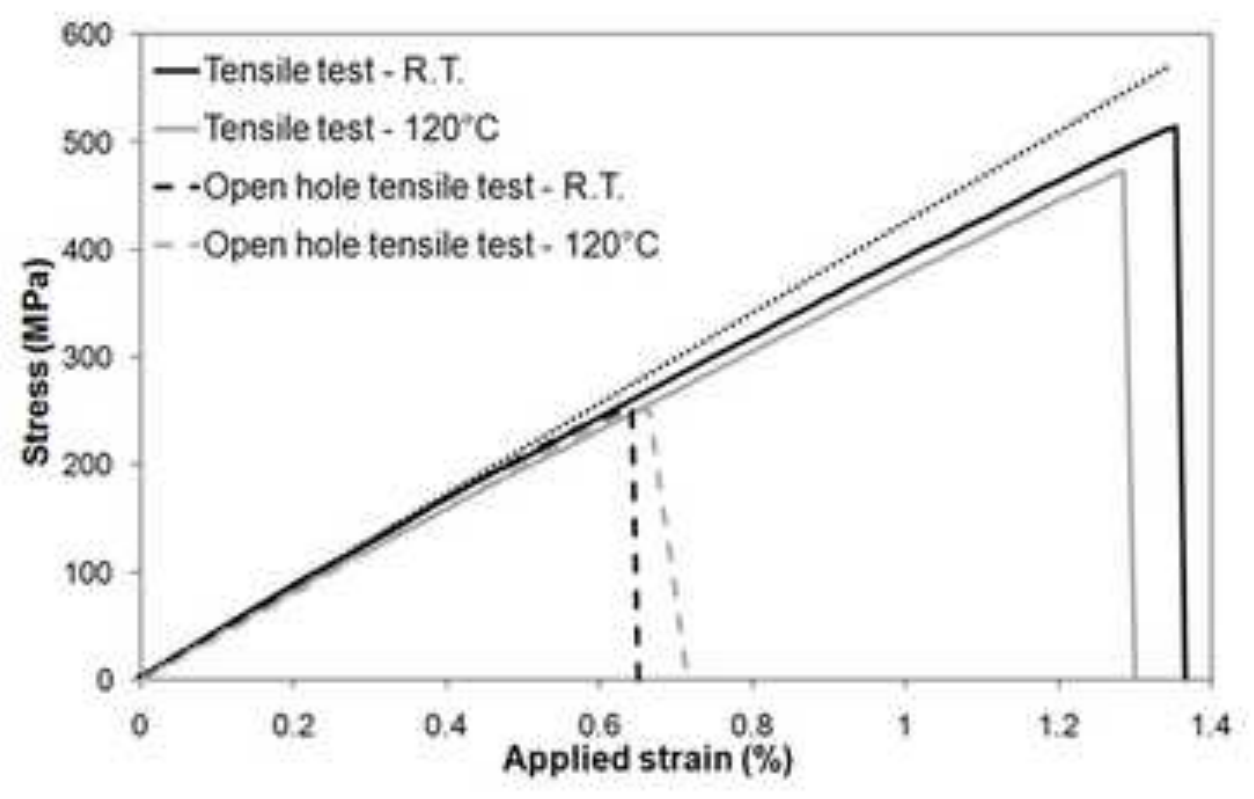

(b)

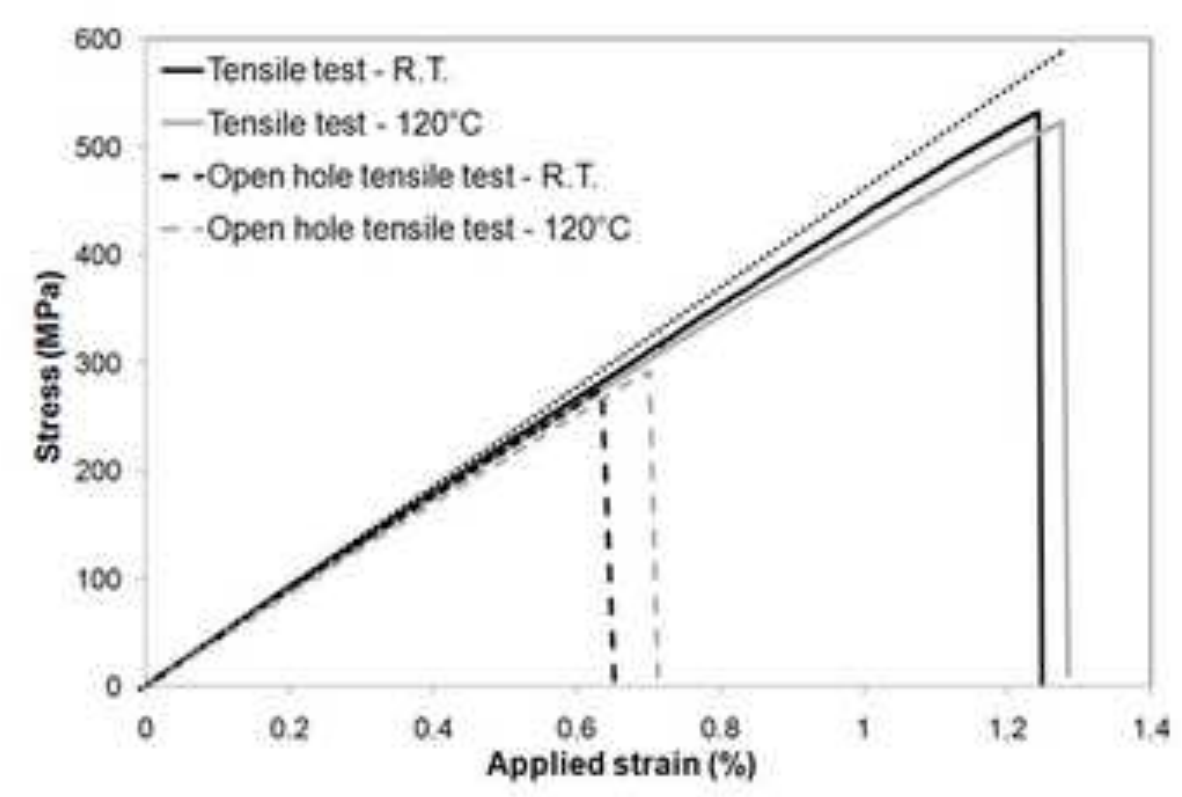




\section{(a)}

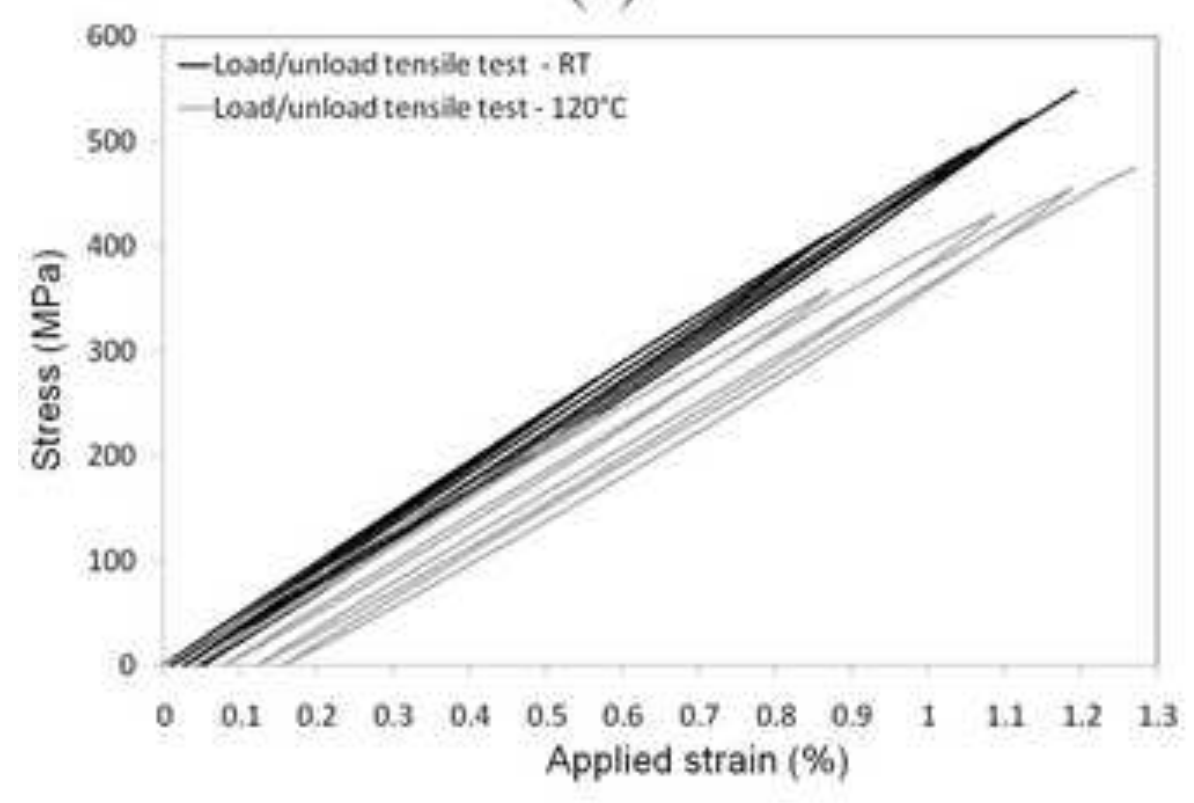

(b)




(a)



(b)

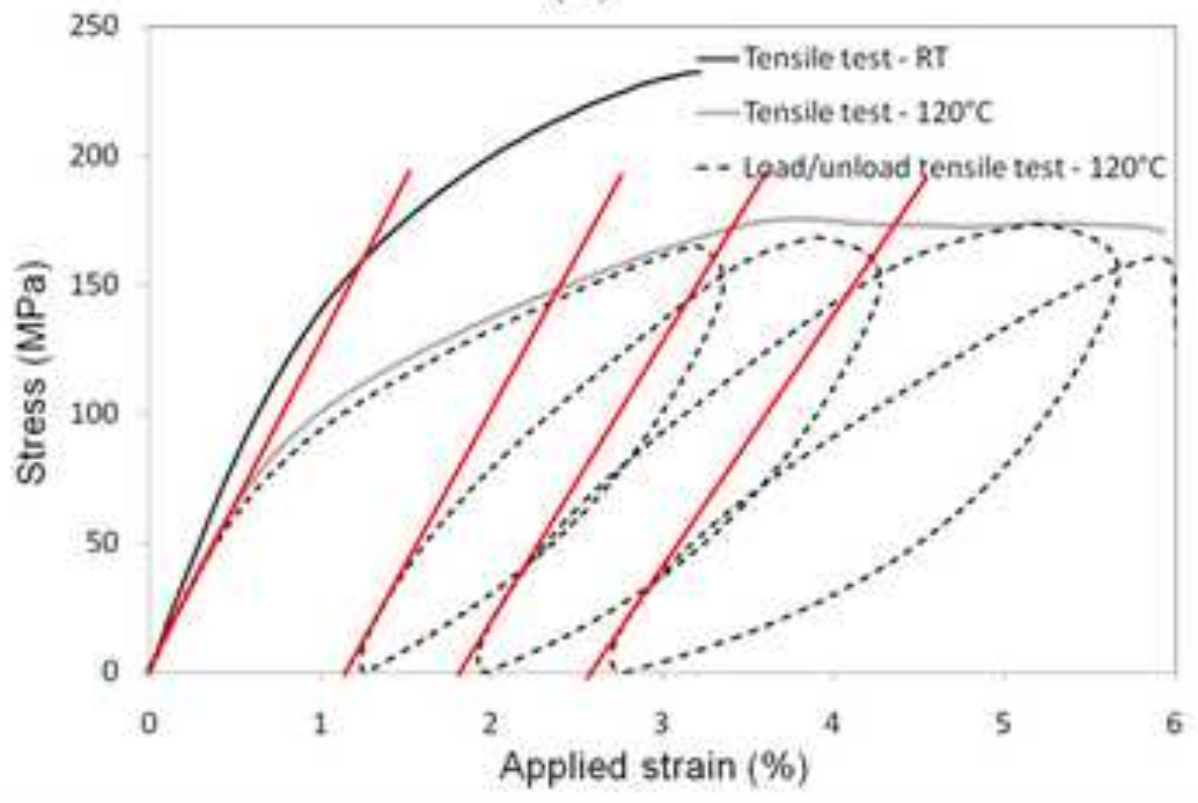


(a)

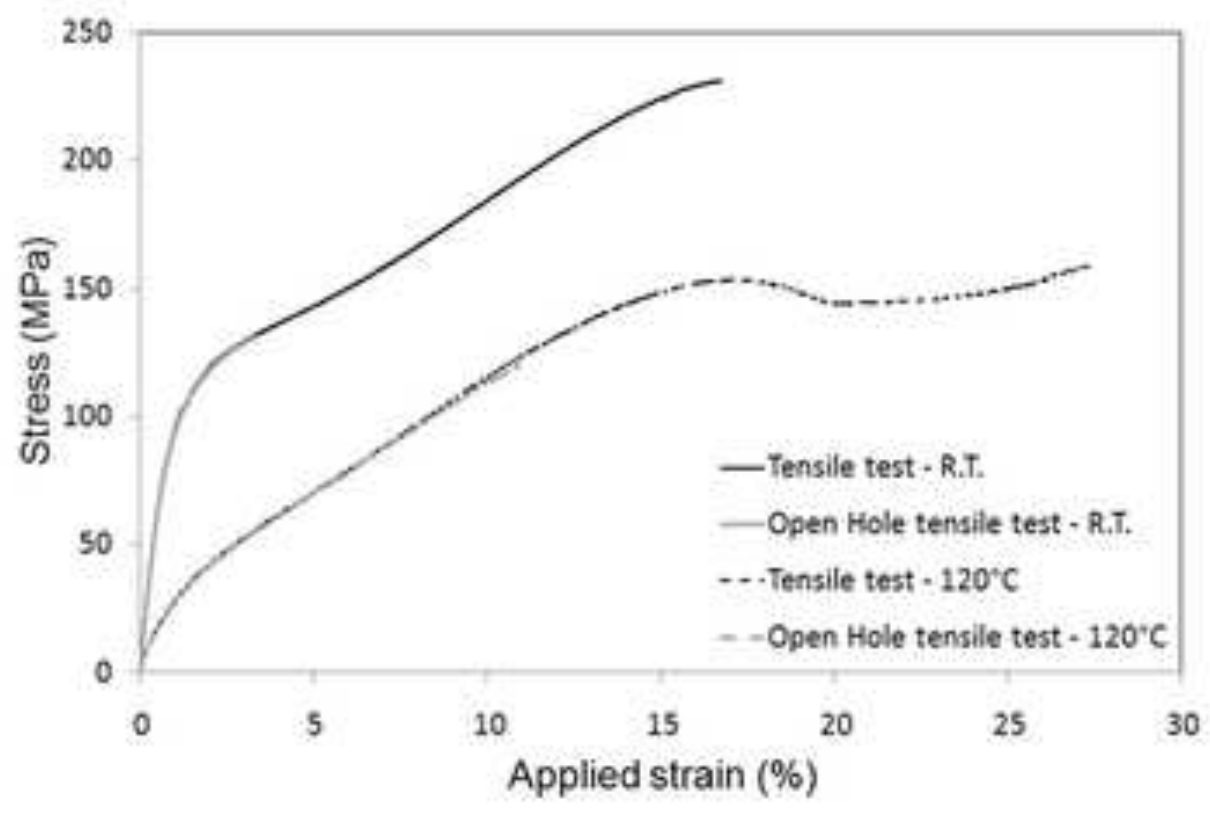

(b)

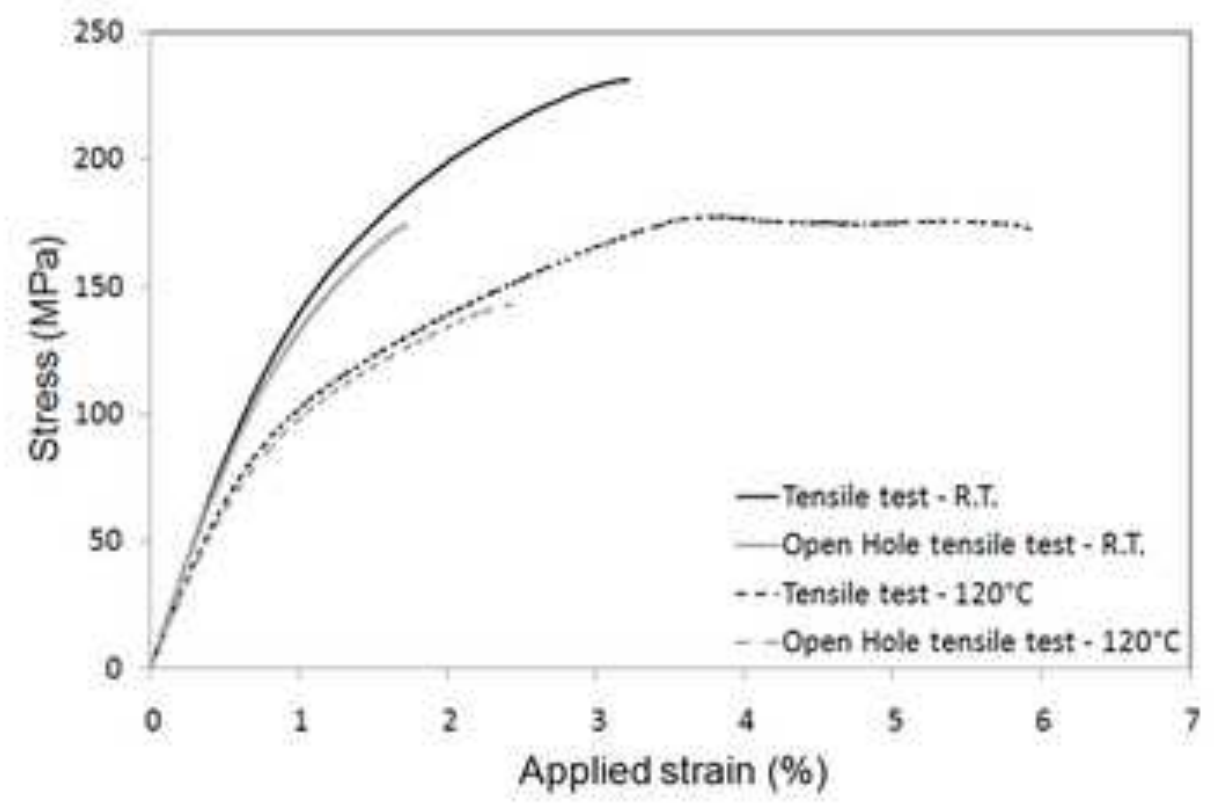




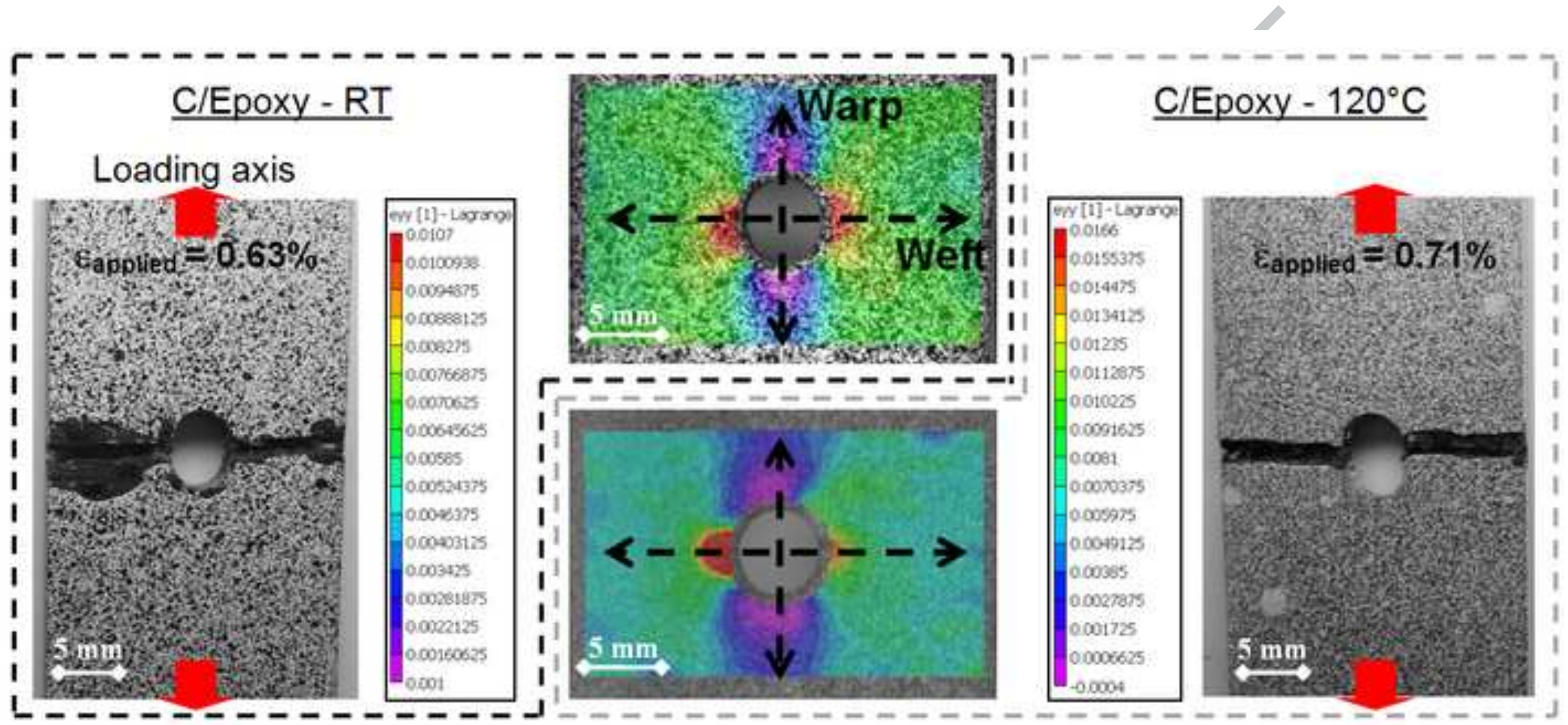




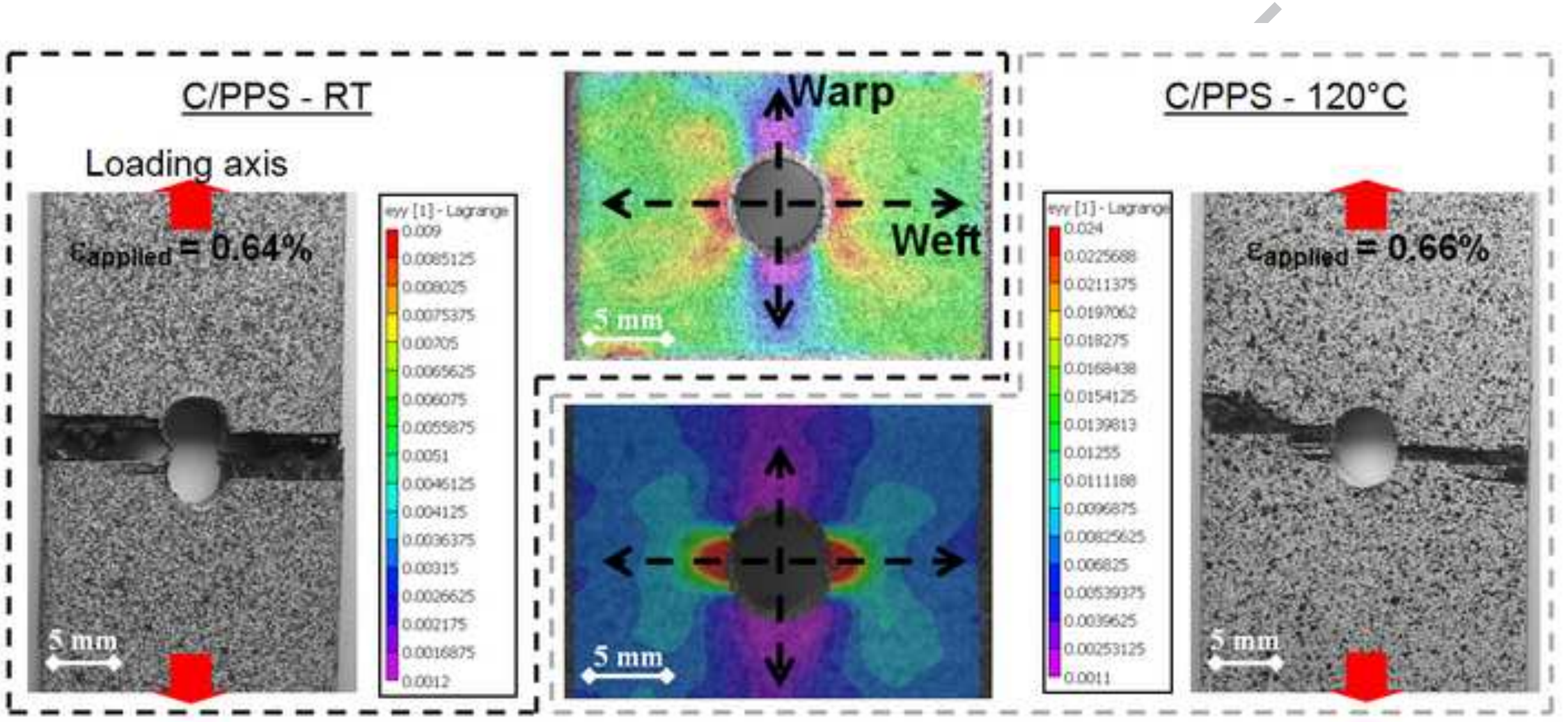








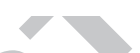




\section{C/PPS - RT}

\section{Loading axis}
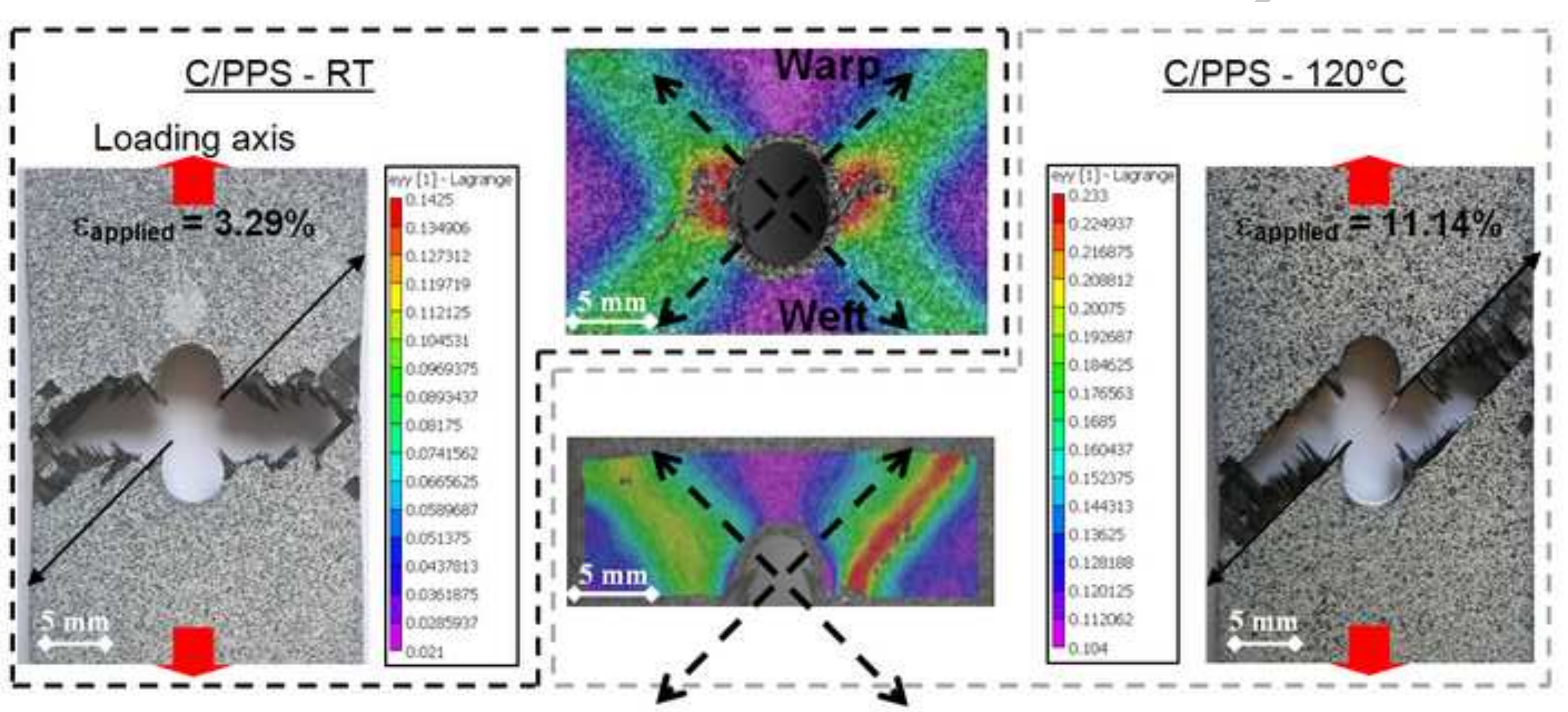
(a)

(b)
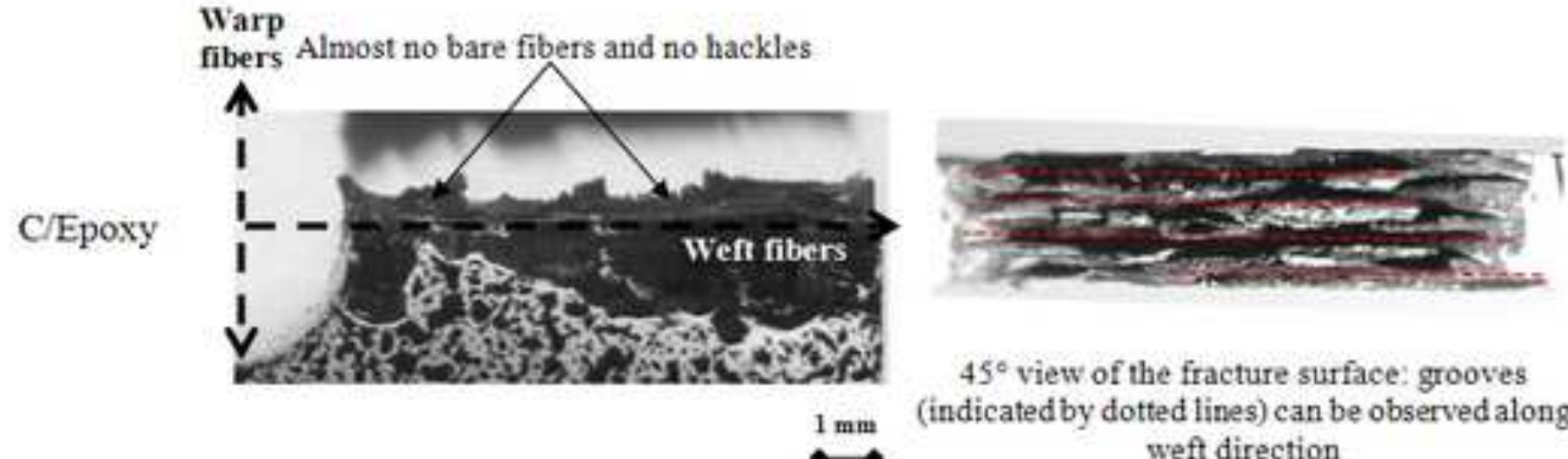

$45^{\circ}$ view of the fracture surface: grooves (indicated by dotted lines) can be observed along

$\bullet$ weft direction

Broken bare fibers in hackles configuration

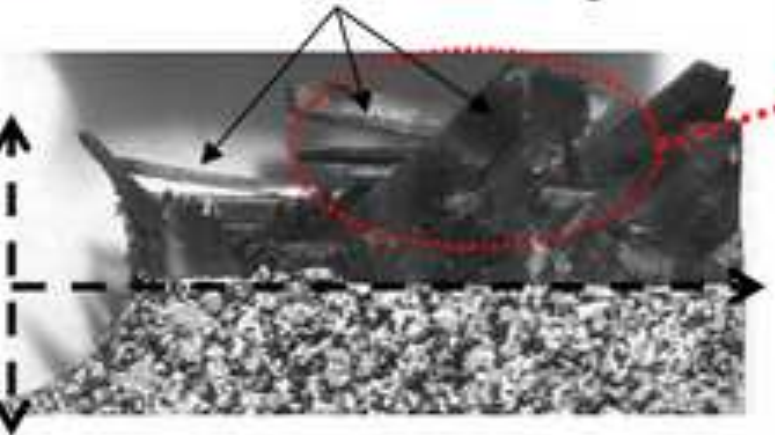

$\stackrel{1}{\operatorname{ma}} \rightarrow$

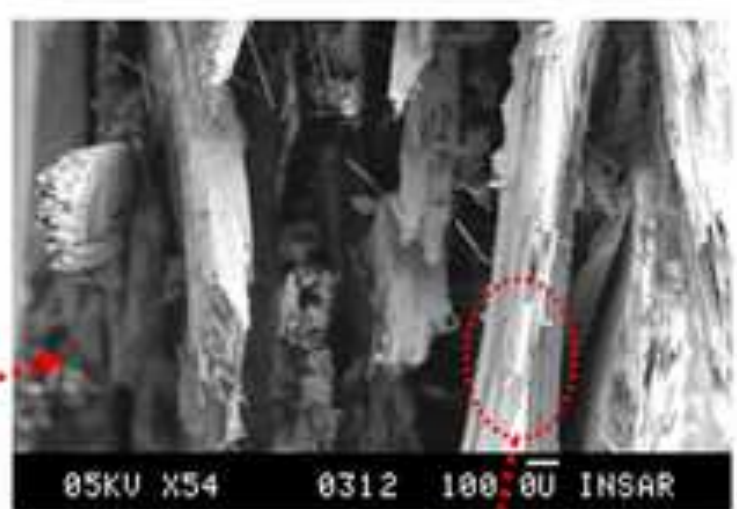

$\mathrm{x} 54$ SEM observations of the front view of fracture surfaces : brokertbare fibers

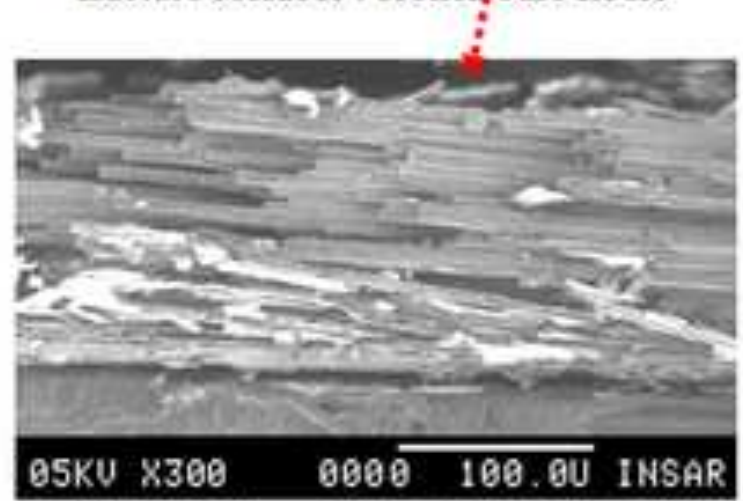

$\mathrm{x} 300$ SEM observation of a fibers bundle: fiber/matrix interface debonding 
(a)

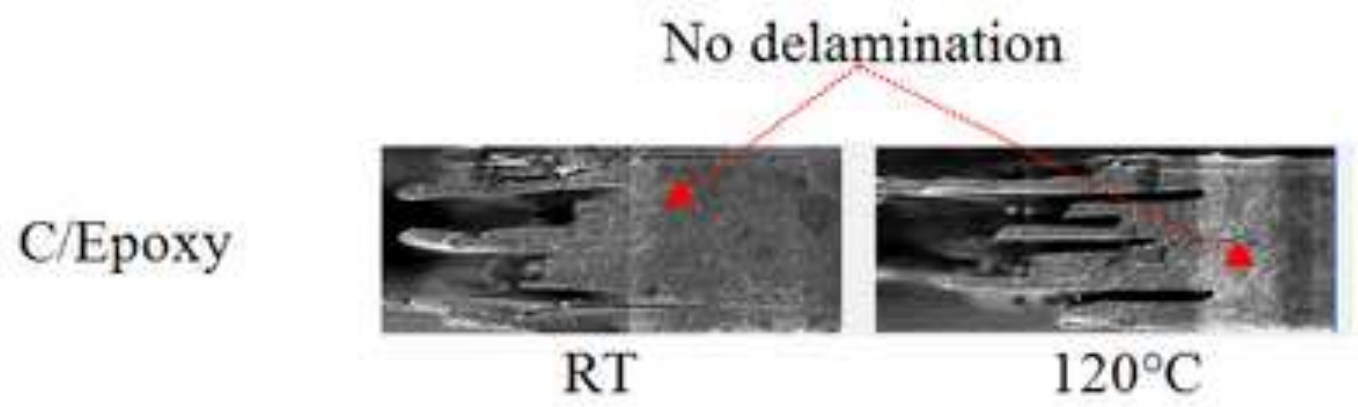

C/PPS

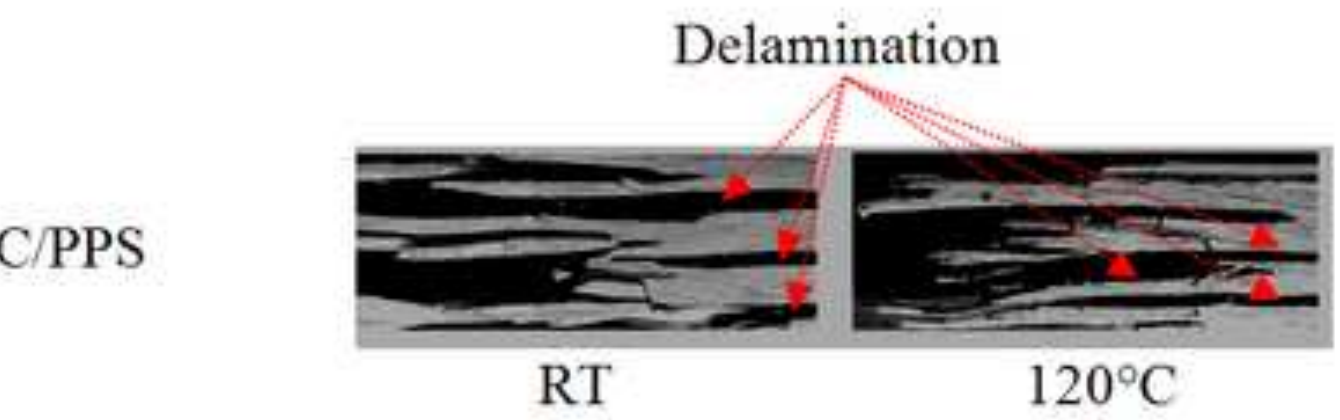

(b)

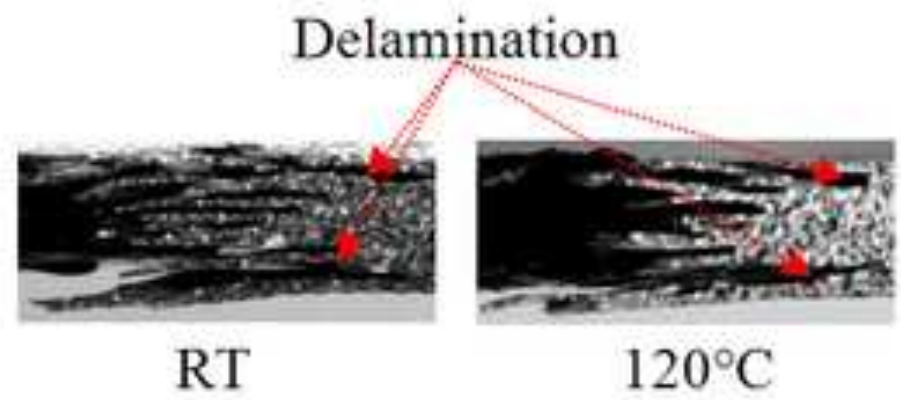

Extensive delamination

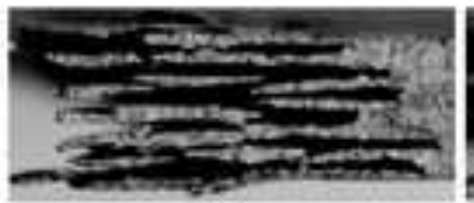

RT

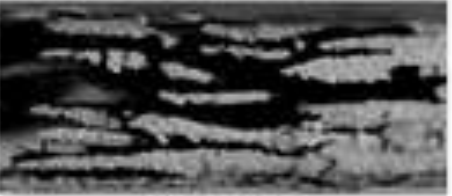

$120^{\circ} \mathrm{C}$

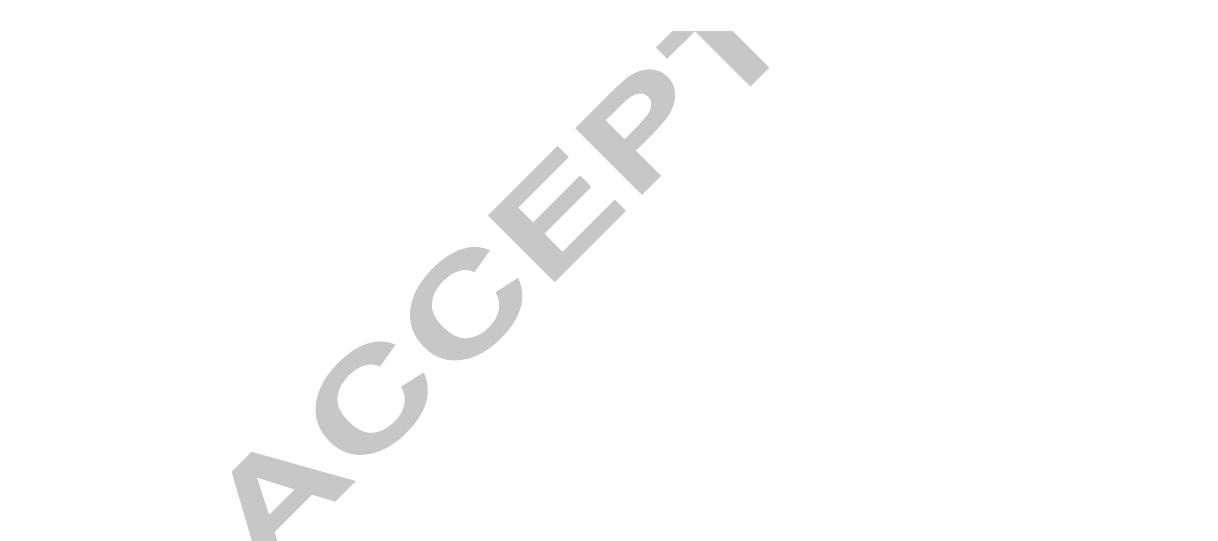


(a) T.A.

C/Epoxy

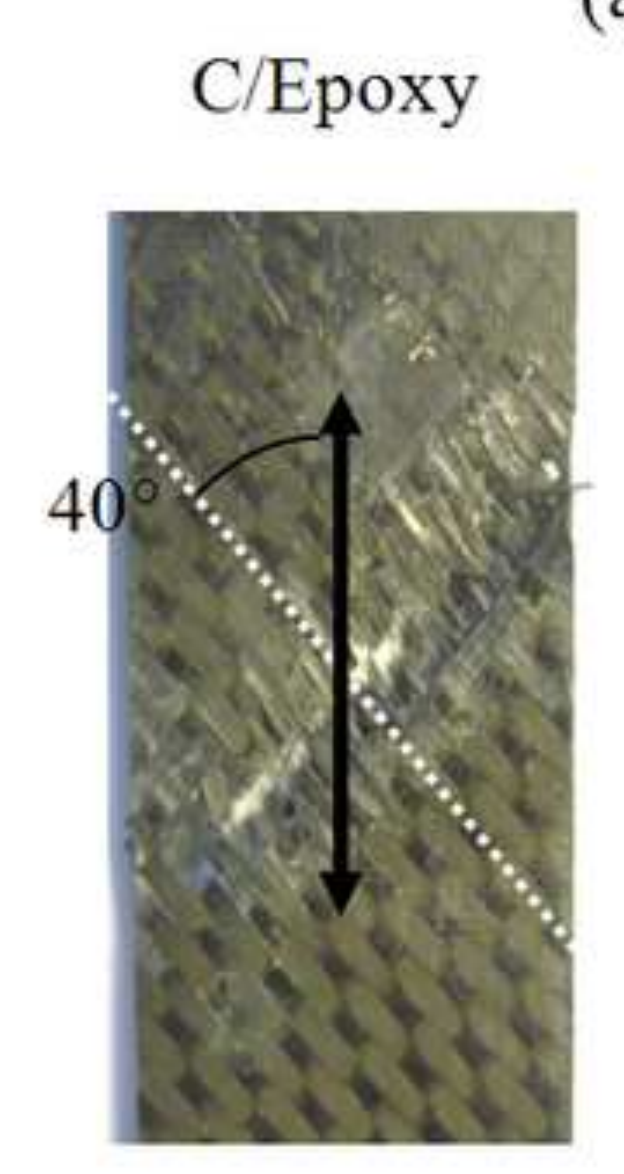

\section{C/PPS}

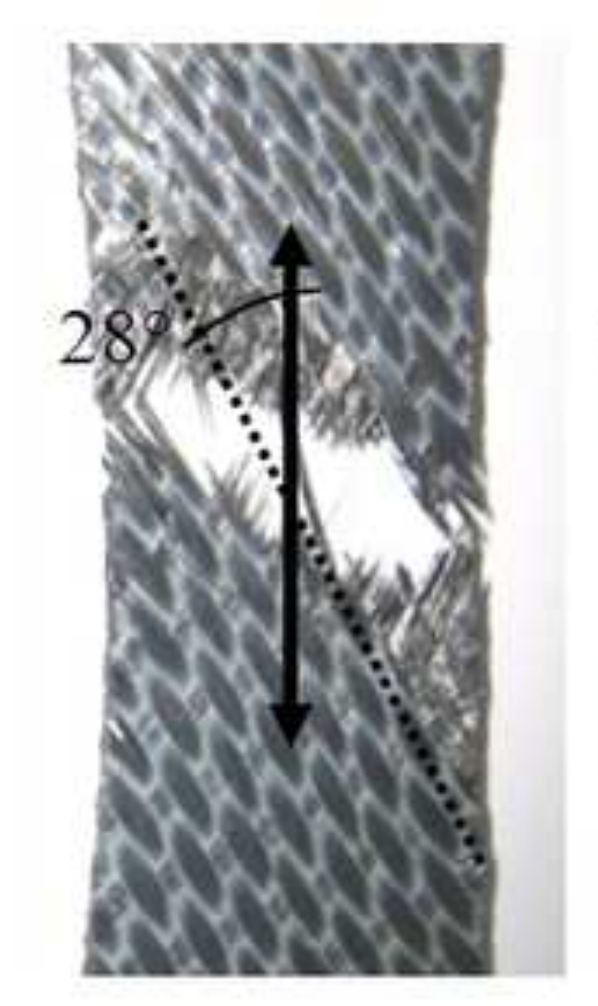

(b) $120^{\circ} \mathrm{C}$

$\mathrm{C} /$ Epoxy

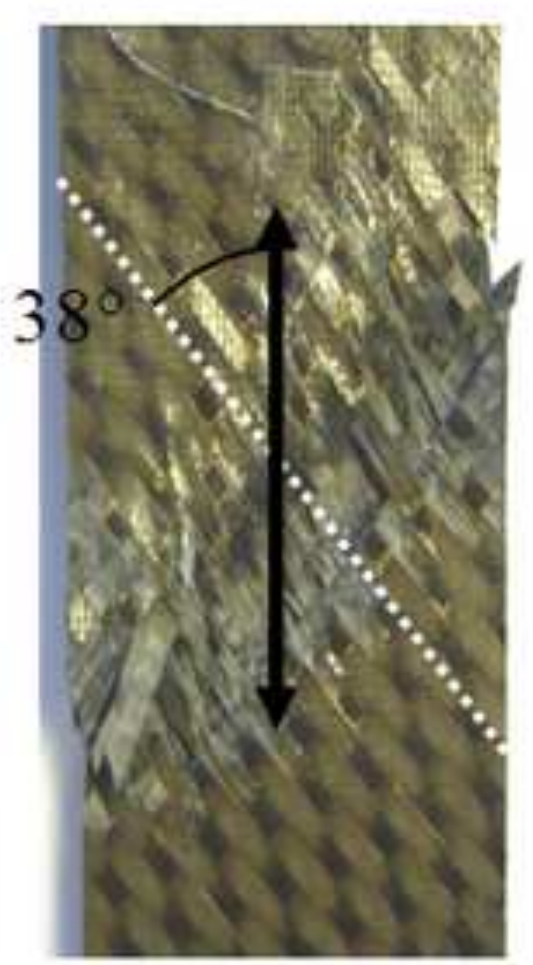

C/PPS






\begin{tabular}{|l|c|c|}
\cline { 2 - 3 } \multicolumn{1}{c|}{} & C/Epoxy & C/PPS \\
\hline$E_{1}(\mathrm{GPa})$ & 63.3 & 56.5 \\
\hline$E_{2}(\mathrm{GPa})$ & 63.3 & 56.5 \\
\hline$G_{12}(\mathrm{GPa})$ & 5.29 & 4.08 \\
\hline$v_{12}$ & 0.04 & 0.04 \\
\hline$\sigma_{1}(\mathrm{MPa})$ & 690 & 700 \\
\hline$\sigma_{2}(\mathrm{MPa})$ & 690 & 700 \\
\hline$\sigma_{12}(\mathrm{MPa})$ & 116 & 115 \\
\hline
\end{tabular}

Tab. 1 - RT mechanical properties of $[0]_{7}$ laminates

(a)

\begin{tabular}{|c|l|c|c|c|c|}
\hline \multicolumn{2}{|c|}{$\sigma^{\text {Unload }} / \sigma^{\text {Falher }}$} & $50 \%$ & $75 \%$ & $90 \%$ & $95 \%$ \\
\hline \multirow{2}{*}{$\begin{array}{c}E_{X}^{\prime} / E_{X}^{0} \\
(\%)\end{array}$} & $\mathrm{RT}$ & 99.6 & 99.5 & 99.2 & 99 \\
\cline { 2 - 6 } & $120^{\circ} \mathrm{C}$ & 99.9 & 99.1 & 96.4 & 96.3 \\
\hline \multirow{2}{*}{$\begin{array}{c}\text { sealdual } \\
(\%)\end{array}$} & $\mathrm{RT}$ & 0.011 & 0.027 & 0.051 & 0.06 \\
\cline { 2 - 6 } & $120^{\circ} \mathrm{C}$ & 0.038 & 0.079 & 0.122 & 0.155 \\
\hline
\end{tabular}

(b)

\begin{tabular}{|c|c|c|c|}
\hline$\sigma^{\text {Unload }} / \sigma^{\text {Fallure }}$ & $90 \%$ & $95 \%$ & $97 \%$ \\
\hline$G_{12} / G_{12}^{0}(\%)$ & 82 & 75 & 62 \\
\hline$\varepsilon_{\text {restdual }}(\%)$ & 1.26 & 1.96 & 2.77 \\
\hline
\end{tabular}

Tab. 2 - Changes in modulus and residual strain of C/Epoxy for different levels of the load at failure: (a) Q-I laminates at RT and $120^{\circ} \mathrm{C}-$ (b) A-P laminates at $120^{\circ} \mathrm{C}$ 


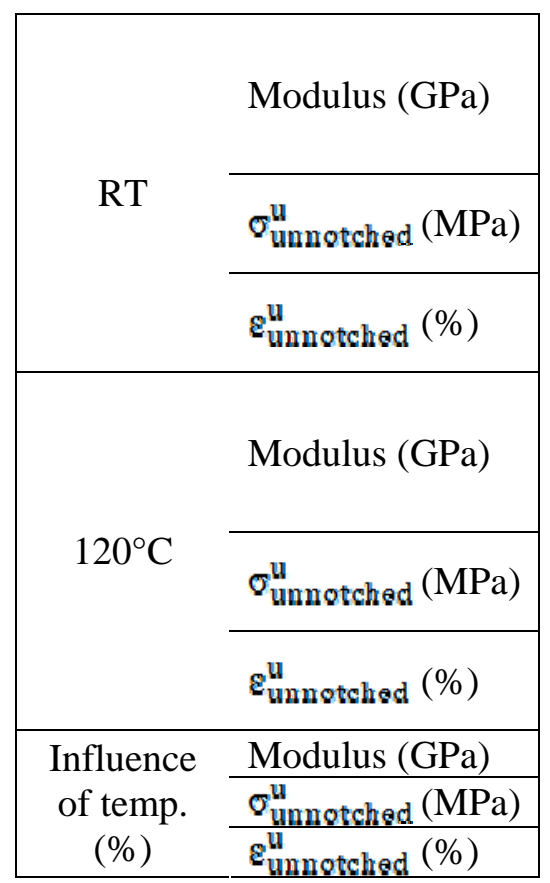

\begin{tabular}{|c|c|c|c|c|c|}
\hline \multicolumn{2}{|c|}{ C/PPS } & \multicolumn{2}{|c|}{ C/Epoxy } & \multicolumn{2}{|c|}{$\frac{\mathrm{C} / \mathrm{PPS}}{\mathrm{C} / \mathrm{ePQxy}}(\%)$} \\
\hline Q-I & $\begin{array}{l}\text { Angle- } \\
\text { ply }\end{array}$ & Q-I & $\begin{array}{l}\text { Angle- } \\
\text { ply }\end{array}$ & Q-I & $\begin{array}{l}\text { Angle- } \\
\text { ply }\end{array}$ \\
\hline $\begin{array}{l}41.39- \\
41.58- \\
42.19- \\
42.65: \\
\mathbf{4 1 . 9 5} \\
\end{array}$ & $\begin{array}{c}3.96-4.02- \\
4.15-4.19: \\
\mathbf{4 . 0 8}\end{array}$ & $\begin{array}{l}44.67- \\
44.82- \\
45.56- \\
45.84: \\
\mathbf{4 5 . 2 2} \\
\end{array}$ & $\begin{array}{c}5.11-5.18- \\
5.39-5.47: \\
\mathbf{5 . 2 9}\end{array}$ & -8 & -23 \\
\hline $\begin{array}{c}504-512- \\
517-523: \\
\mathbf{5 1 4} \\
\end{array}$ & $\begin{array}{c}224-227- \\
\text { 235-237: } \\
\mathbf{2 3 1} \\
\end{array}$ & $\begin{array}{c}522-528- \\
538-541: \\
532\end{array}$ & $\begin{array}{c}222-233- \\
236-238: \\
\mathbf{2 3 2} \\
\end{array}$ & -3 & \\
\hline $\begin{array}{c}1.32-1.34- \\
1.36-1.37: \\
\mathbf{1 . 3 5}\end{array}$ & $\begin{array}{c}16.59-16.72- \\
\text { 16.82-16.91: } \\
\mathbf{1 6 . 7 6}\end{array}$ & $\begin{array}{c}1.21-1.24- \\
1.24-1.26: \\
\mathbf{1 . 2 4}\end{array}$ & $\begin{array}{c}3.17-3.19- \\
3.24-3.28: \\
3.22\end{array}$ & +5 & \\
\hline $\begin{array}{l}40.18- \\
40.29- \\
40.68- \\
40.81: \\
\mathbf{4 0 . 4 9}\end{array}$ & $\begin{array}{l}\text { 1.29-1.33- } \\
\text { 1.38-1.4: } \\
\mathbf{1 . 3 5}\end{array}$ & $\begin{array}{l}42.48- \\
43.05- \\
43.76- \\
43.86: \\
\mathbf{4 3 . 2 9}\end{array}$ & $\begin{array}{c}4.11-4.14- \\
4.24-4.28: \\
\mathbf{4 . 1 9}\end{array}$ & & -68 \\
\hline $\begin{array}{c}464-472- \\
475-478: \\
\mathbf{4 7 2}\end{array}$ & $\begin{array}{c}155-15- \\
160-164: \\
\mathbf{1 5 9}\end{array}$ & $\begin{array}{l}\text { 497-502- } \\
\text { 507-515: } \\
\mathbf{5 0 5}\end{array}$ & $\begin{array}{c}166-169- \\
\text { 180-185: } \\
\mathbf{1 7 5}\end{array}$ & -6 & -10 \\
\hline $\begin{array}{c}1.24-1.6- \\
1.31-1.32: \\
\mathbf{1 . 2 8}\end{array}$ & $\begin{array}{c}27.03-27.22- \\
27.45-27.65: \\
\mathbf{2 7 . 3 4}\end{array}$ & $\begin{array}{c}1.24-1.26- \\
1.31-1.32: \\
\mathbf{1 . 2 8}\end{array}$ & $\begin{array}{c}5.73-5.79- \\
5.89-5.98: \\
\mathbf{5 . 8 5}\end{array}$ & +8 & +367 \\
\hline-3 & -67 & -4 & -21 & & \\
\hline-8 & -31 & -5 & -25 & & \\
\hline-5 & +63 & +3 & +82 & & \\
\hline
\end{tabular}

Tab. 3 - Tensile mechanical properties (individual test values and average) at both temperatures for both materials: quasi-isotropic and angle-ply laminates

\begin{tabular}{|c|c|c|c|c|c|c|}
\hline & \multicolumn{2}{|c|}{$\sigma_{\text {Rnnatched }}^{\text {falculated }}(\mathrm{MPa})$} & \multicolumn{2}{|c|}{$\sigma_{\text {unnatched }}^{\text {exp }}(\mathrm{MPa})$} & \multicolumn{2}{|c|}{ R.C. (\%) } \\
\hline & Q-I & {$[45]_{7}$} & Q-I & {$[45]_{7}$} & Q-I & {$[45]_{7}$} \\
\hline & 482 & 229 & 532 & 232 & -9.4 & -1.3 \\
\hline C/PPS & 527 & 249 & 514 & 231 & +2.2 & +7.8 \\
\hline
\end{tabular}

Tab. 4 - Calculated vs experimental failure strengths: quasi-isotropic and angle-ply laminates 


\begin{tabular}{|c|c|}
\hline \multirow{3}{*}{ RT } & $\sigma_{\text {uelched }}^{\mathrm{u}}(\mathrm{MPa})$ \\
\hline & $\mathrm{C}_{\mathrm{h}}$ \\
\hline & $\mathrm{\varepsilon}_{\text {netched }}^{\mathrm{u}}(\%)$ \\
\hline \multirow{3}{*}{$120^{\circ} \mathrm{C}$} & $\sigma_{\text {motched }}^{\mathrm{u}}(\mathrm{MPa})$ \\
\hline & $\mathrm{C}_{\mathrm{h}}$ \\
\hline & $\mathrm{e}_{\text {notched }}^{\mathrm{u}}(\%)$ \\
\hline \multirow{3}{*}{$\begin{array}{c}\text { Influence of } \\
\text { temperature } \\
(\%)\end{array}$} & $\sigma_{\text {motched }}^{\mathrm{u}}(\mathrm{MPa})$ \\
\hline & $\mathrm{C}_{\mathrm{h}}$ \\
\hline & $\mathrm{s}_{\text {notched }}^{\mathrm{u}}(\%)$ \\
\hline
\end{tabular}

\begin{tabular}{|c|c|c|c|c|c|}
\hline \multicolumn{2}{|c|}{ C/PPS } & \multicolumn{2}{|c|}{ C/Epoxy } & \multicolumn{2}{|c|}{$\frac{\text { C/PPS }}{\text { C/Qpoxy }}(\%)$} \\
\hline Q-I & $\begin{array}{l}\text { Angle- } \\
\text { ply }\end{array}$ & Q-I & $\begin{array}{l}\text { Angle- } \\
\text { ply }\end{array}$ & Q-I & $\begin{array}{l}\text { Angle- } \\
\text { ply }\end{array}$ \\
\hline $\begin{array}{c}246-251- \\
258-264: \\
255 \\
\end{array}$ & $\begin{array}{c}124-125- \\
137-138: \\
\mathbf{1 3 1} \\
\end{array}$ & $\begin{array}{c}269-273- \\
\text { 276-287: } \\
\mathbf{2 7 6} \\
\end{array}$ & $\begin{array}{c}172-172- \\
\text { 173-183: } \\
\mathbf{1 7 5} \\
\end{array}$ & -8 & -25 \\
\hline 0.5 & 0.57 & 0.52 & 0.75 & -4 & -24 \\
\hline $\begin{array}{l}0.61-0.63- \\
0.65-0.66: \\
\mathbf{0 . 6 4}\end{array}$ & $\begin{array}{l}\text { 3.24-3.26- } \\
\text { 3.31-3.35: } \\
\mathbf{3 . 2 9}\end{array}$ & $\begin{array}{c}0.61-0.62- \\
0.65-0.65: \\
\mathbf{0 . 6 3}\end{array}$ & $\begin{array}{c}1.68-1.71- \\
1.72-1.77: \\
\mathbf{1 . 7 2}\end{array}$ & +2 & \\
\hline $\begin{array}{c}237-244- \\
249-259: \\
247\end{array}$ & $\begin{array}{c}115-119- \\
123-127: \\
\mathbf{1 2 1}\end{array}$ & $\begin{array}{c}281-291- \\
\text { 295-302: } \\
\mathbf{2 9 2}\end{array}$ & $\begin{array}{c}139-140- \\
145-152: \\
\mathbf{1 4 4} \\
\end{array}$ & & \\
\hline 0.52 & 0.76 & 0.58 & 0.82 & -11 & -7 \\
\hline $\begin{array}{c}0.64-0.65- \\
0.66-0.69: \\
\mathbf{0 . 6 6} \\
\end{array}$ & $\begin{array}{c}11.05-11.11 \\
\text { 11.17-11.24: } \\
\mathbf{1 1 . 1 4}\end{array}$ & $\begin{array}{c}0.68-0.71- \\
0.72-0.73: \\
\mathbf{0 . 7 1} \\
\end{array}$ & $\begin{array}{c}2.4-2.42- \\
2.43-2.51: \\
\mathbf{2 . 4 4}\end{array}$ & -5 & +356 \\
\hline-3 & -8 & +6 & -18 & & \\
\hline+4.0 & +34 & +11 & +9 & & \\
\hline+3 & +238 & +3 & +38 & & \\
\hline
\end{tabular}

Tab. 5 - Open-hole tensile mechanical properties (individual test values and average) at both temperatures for both materials: quasi-isotropic and angle-ply laminates

\begin{tabular}{|c|c|c|c|c|c|}
\hline \multirow{3}{*}{ RT } & $\mathrm{e}_{\text {notched }}^{\mathrm{u}}(\%)$ & 0.64 & 3.29 & 0.63 & 1.72 \\
\hline & Max. overstrain (\%) & 0.9 & 14.25 & 1.07 & 5.75 \\
\hline & Overstrain coefficient & 1.41 & 4.33 & 1.70 & 3.34 \\
\hline \multirow{3}{*}{$120^{\circ} \mathrm{C}$} & $\varepsilon_{\text {notched }}^{\text {u }}(\%)$ & 0.66 & 11.14 & 0.71 & 2.44 \\
\hline & Max. overstrain (\%) & 2.4 & 23.3 & 1.66 & 8.65 \\
\hline & Overstrain coefficient & 3.64 & 2.09 & 2.37 & 3.54 \\
\hline \multicolumn{2}{|c|}{$\begin{array}{l}\text { Influence of temperature on the } \\
\text { overstrain coef. (\%) }\end{array}$} & +158 & -52 & +40 & +6 \\
\hline
\end{tabular}

Tab. 6 - Changes in overstrain coefficients for both materials 